\title{
Growth and demise of a Paleogene isolated carbonate platform of the Offshore Indus Basin, Pakistan: effects of regional and local controlling factors
}

\author{
Khurram Shahzad $^{1}$ - Christian Betzler ${ }^{1}$ - Nadeem Ahmed ${ }^{2}$ Farrukh Qayyum ${ }^{1}$. \\ Silvia Spezzaferri ${ }^{3} \cdot{\text { Anwar } \text { Qadir }^{4}}^{4}$
}

\begin{abstract}
Based on high-resolution seismic and well datasets, this paper examines the evolution and drowning history of a Paleocene-Eocene carbonate platform in the Offshore Indus Basin of Pakistan. This study uses the internal seismic architecture, well log data as well as the microfauna to reconstruct factors that governed the carbonate platform growth and demise. Carbonates dominated by larger benthic foraminifera assemblages permit constraining the ages of the major evolutionary steps and show that the depositional environment was tropical within oligotrophic conditions. With the aid of seismic stratigraphy, the carbonate platform edifice is resolved into seven seismic units which in turn are grouped into three packages that reflect its evolution from platform initiation, aggradation with escarpment formation and platform drowning. The carbonate factory initiated as mounds and patches on a Cretaceous-Paleocene volcanic complex. Further, the growth history of the platform includes distinct phases of intraplatform progradation, aggradation, backstepping and partial drownings. The youngest succession as late-stage buildup records a shift from benthic to pelagic deposition and marks the final drowning in the Early Eocene. The
\end{abstract}

Khurram Shahzad

khurram.shahzad@uni-hamburg.de

Institut für Geologie, Universität Hamburg, Bundesstraße 55, 20146 Hamburg, Germany

2 MOL Pakistan Oil and Gas Co, B.V, Plot No. 5/A, Crown Plaza, F-7 Markaz, Islamabad, Pakistan

3 Department of Geosciences, University of Fribourg, Chemin Du Musée 6, Fribourg, Switzerland

4 Department of Geology, University of Haripur, Hattar Road, Haripur, Pakistan depositional trend of the platform, controlled by the continuing thermal subsidence associated with the cooling of volcanic margin lithosphere, was the major contributor of the accommodation space which supported the vertical accumulation of shallow water carbonate succession. Other factors such as eustatic changes and changes in the carbonate producers as a response to the Paleogene climatic perturbations played secondary roles in the development and drowning of these buildups.

Keywords Paleogene carbonate platform - Seismic sequence stratigraphy · Drowning · Offshore Indus Basin • Larger benthic foraminifera $\cdot$ Biostratigraphy

\section{Introduction}

Paleogene carbonate platforms have been intensively studied over the last few decades with respect to sea level changes, shallow benthic biostratigraphy (Serra-Kiel et al. 1998; Scheibner and Speijer 2009; Courgeon et al. 2016), paleoclimate (Scheibner et al. 2005, 2007; Scheibner and Speijer 2008a; Robinson 2011), environmental conditions (Hallock et al. 1991), reconstruction of depositional systems and lithofacies of economic importance (Mresah 1993; Jorry et al. 2003; Scheibner et al. 2007; Zamagni et al. 2008; Höntzsch et al. 2011). The Paleogene was a time of major reorganizations of continents and significant climate fluctuations such as the Paleocene-Eocene thermal maximum (PETM) which culminated with the Early Eocene Climatic Optimum (EECO). These events were marked by a prominent negative carbon isotope excursion (CIE) and carbonate dissolution in deep-sea sediment records (Zachos 2001). Shallow water carbonate platforms are acutely sensitive to such climatic 
fluctuations and are fundamental archives encoding these environmental changes (Schlager 1981; Hallock and Schlager 1986; Schlager and Camber 1986; Betzler et al. 2000, 2009, 2013).

Carbonate platforms develop as a result of different factors including tectonic, climate, eustatic variations, siliciclastic and nutrient availability, and environmental conditions (Schlager 2005). These factors determine the relationship between carbonate production and accommodation space. Hence, they control the internal sedimentary architecture and facies distribution of the carbonate buildups (Sarg 1988; Sarg et al. 1999). Seismic interpretation becomes challenging when the carbonate depositional cycles operate over a magnitude of a few meters. This problem leaves behind a poorly resolved stratigraphic pattern (e.g., progradation) on a seismic scale. In this situation, seismic data show an overall aggradational section, which can mistakenly be interpreted as a highstand or a transgressive systems tract. Herein, the question of sequence internal stratification is elucidated by applying the HorizonCube method (Qayyum et al. 2012, 2013).
On the northwestern periphery of the Indian Plate, covering an area of $3500 \mathrm{~km}^{2}$, the Paleogene carbonate system represents the largest isolated carbonate platform system of the region (Fig. 1). In the past, regional studies on tectonic and stratigraphic framework of these buildups have been performed. However, they did not address the internal stratigraphic architecture of these carbonate platforms and buildups (Carmichael et al. 2009), which is a key for understanding the evolution of these platform.

Considering the current research gaps, this study investigates the architectural evolution and drowning history of one of the Paleogene carbonate platform of the Offshore Indus Basin, Pakistan, through a comprehensive analysis of regional 2D seismic profiles and well data. In the light of seismic stratigraphic concepts and facies analysis, this study focuses on internal reflection geometry to trace the development phases and assess the intrinsic and extrinsic factors that governed the carbonate growth and demise. Furthermore, this study documents the biotic assemblages and constrains the ages of the major evolutionary stages of platform growth and final drowning based on the biostratigraphic analysis. Thus, the outcomes have significant
Fig. 1 Geographical position of the Offshore Indus Basin. Bathymetry after Ryan et al. (2009). The study area is marked with the black rectangle and its position relative to the Indian Ocean is shown in the bottom right corner

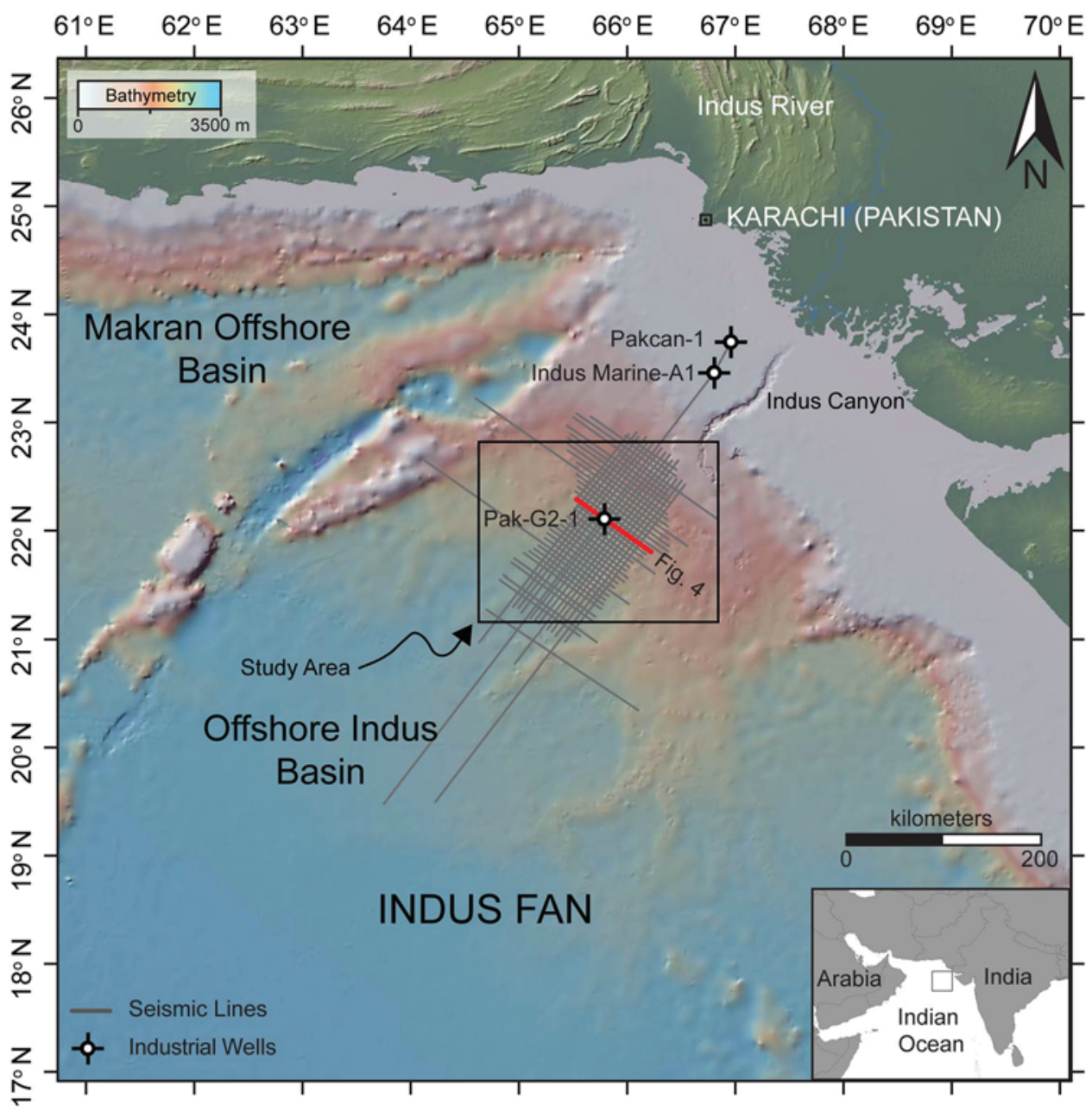


implications for the understanding of the evolution of carbonate platforms, which indirectly helps better in predicting the depositional system and lithofacies of economic importance. The depositional model as reconstructed through this study may also serve as an analog to the subsurface carbonate platforms elsewhere.

\section{Geological background}

The Offshore Indus Basin is located in the eastern part of the Arabian Sea, on the northwestern margin of the Indian Plate. Tectonically, the basin is bounded by the Murray Ridge-Owen Fracture Zone in the northwest (Fig. 2a), which is a major plate boundary between the Indian and Arabian Plate (Edwards et al. 2000). To the north, it is facing the present-day continental shelf which is cut by the Indus Canyon and to the south it bounded by the Carlsberg Ridge. A subsurface buried structure is identified as the Laxmi Ridge in the southeast of the basin and assumed to be a continental product of the early stages of Indian Plate drift (Naini and Talwani 1982; Talwani and Reif 1998). Two buried shield volcanoes, the Somnath Ridge and the Saurashtra High, which form prolific structural features of the basins, are hosting carbonate platforms (Malod et al. 1997;
Calvès et al. 2011). The crustal thickness in the region varies between 9 and $11.5 \mathrm{~km}$ (Calvès et al. 2008). Geohistory analyses, performed by various researchers, indicate a thermal subsidence phase with cooling of the Pakistan volcanic margin, followed by the induced flexuring responsible for the basin development through the Cenozoic (Mohan 1985; Agrawal and Rogers 1992; Whiting et al. 1994).

The tectonic elements of the Indus Basin encompass over 200 million years of geological history (Gaedicke et al. 2002; Chatterjee et al. 2013). The development of the western Indian margins started with the Early Jurassic breakup of the supercontinent Gondwana into East Gondwana, comprising Antarctica, Madagascar, India, and Australia, and West Gondwana, comprising Africa. During the Early Cretaceous, the Indian Plate started to detach from the Antarctic and the Australian Plates and drifted northward (Chatterjee et al. 2013). Further rifting resulted in the separation of the Madagascar and the Indian Plate (Edwards et al. 2000). This rifting phase was followed by the rapid northward drift of the Indian Plate coupled with a counterclockwise rotation (Copley et al. 2010). During this time, the Seychelles and India passed over the Réunion hotspot and extensive volcanic activity occurred with the extrusion of the Deccan lava during the Late Cretaceous and Early Paleocene (Duncan 1990; Todal and Edholm 1998). As a
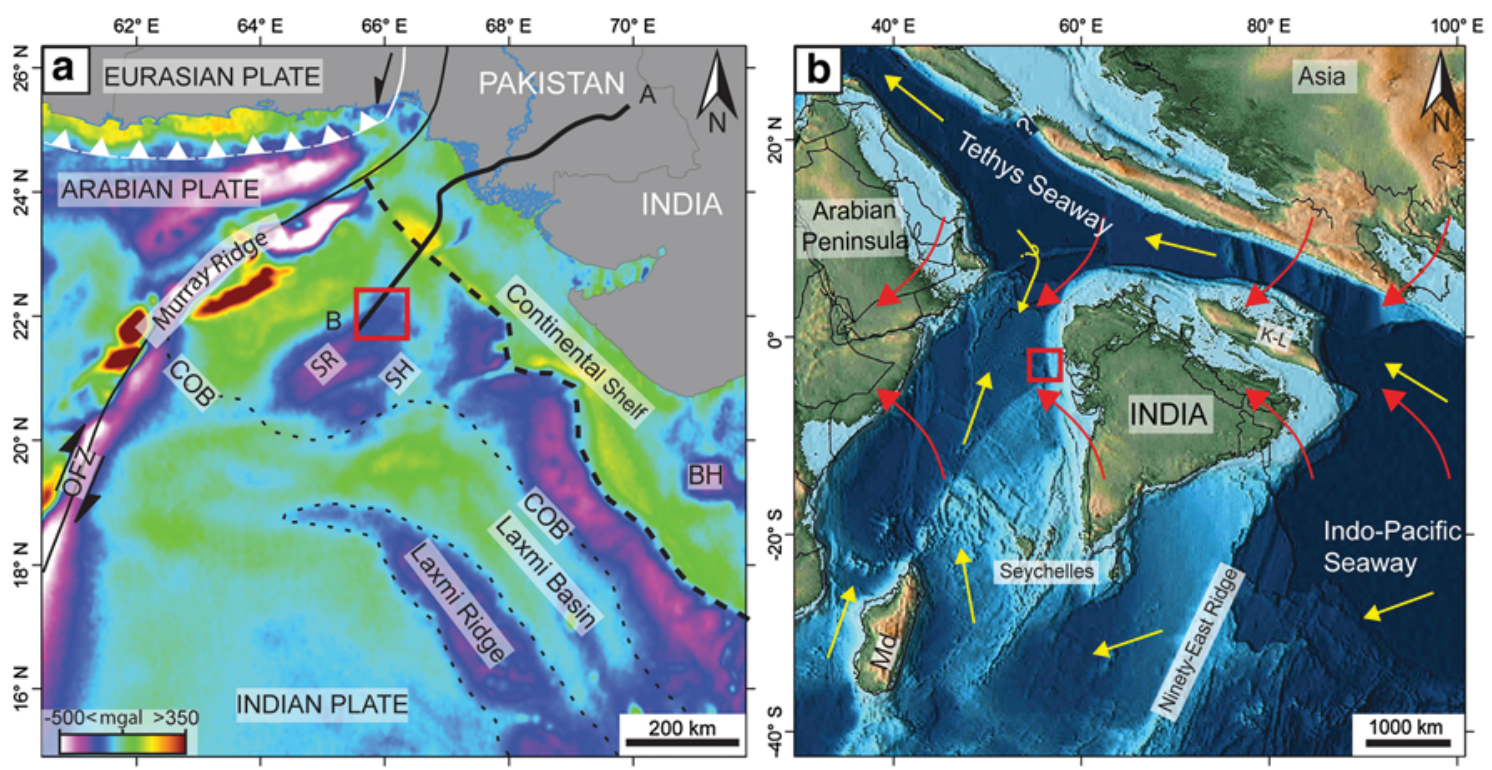

Legend:
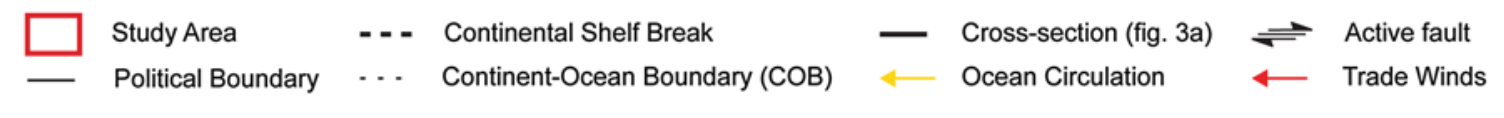

Fig. 2 a Map of tectonic and structural elements of the northwestern margin of the Indian Plate and surroundings with the free air gravity (Sandwell et al. 2014). The bold black line indicates the position of the cross section in Fig. 3. The dotted line labeled with "COB" marks the continent-ocean boundary (after Carmichael et al. 2009).

OFZ Owen-Fracture Zone, SR Somnath Ridge, SH Saurashtra High, $B H$ Bombay High. b Late Paleocene reconstruction ( 56 Ma) and paleogeography of Indian Plate to show the tropical environment with ocean circulation and prevailing wind direction (Haq 1981; Aubert and Droxler 1996; Scotese 2001). Md Madagascar 
result, a chain of volcanic ridges was formed. This event was also accompanied by the separation of the Seychelles from the Indian Plate, (White and McKenzie 1989; Todal and Edholm 1998; Calvès et al. 2011) and formation of a new sea-floor spreading center (Carlsberg Ridge) in the Indian Ocean (Whiting et al. 1994). Passive margin developed during the post-volcanic event that would become the modern day continental shelf.

Following the Deccan volcanism, tropical carbonate platforms developed on the resultant volcanic seamounts (Fig. 2b), while the plate itself was drifting northward with a speed of 15-20 cm/year. (Copley et al. 2010). This northward movement of the Indian Plate was slowed by the oblique collision with the Eurasian Plate and docking with the Ladakh-Kohistan Island Arc in Late Paleocene to Middle Eocene time. Subsequently, the Tethyan Seaway located in the northwest closed during the Late Eocene-Oligocene. This was followed by a mountain building process and a massive influx of terrigenous sediments in the adjacent seas and nearby foredeep, terminating the carbonate sedimentation which developed the world second largest submarine fan system in the Indian Ocean, the Indus Fan (Clift et al. 2001; Wandrey et al. 2004). An increase of the sediment supply to the Indus Fan is known since Late Oligocene. Increased sedimentation rates between the Early and Middle Miocene ( 16 to $11 \mathrm{Ma})$ may reflect the prominent uplift of the Himalaya. Further, Clift et al. (2001) speculated that the exhumation of the Indus drainage basin was later followed by a decrease in sediment influx in the Late Miocene. Today, the basin contains a $9 \mathrm{~km}$ thick succession of Tertiary sediments (Gaedicke et al. 2002; Carmichael et al. 2009).

\section{Stratigraphic framework of the Paleogene carbonates}

The offshore region of Pakistan is still considered as a frontier basin with respect to geological studies and no formal lithostratigraphic scheme has been established yet. The basin stratigraphy consists of (1) a Late Cretaceous to Early Paleocene igneous basement with volcanics and volcaniclastics, broadly known as Deccan volcanics, (2) Paleocene-Eocene shallow marine isolated carbonate platforms, settled on the volcanic highs, (3) Paleocene-Oligocene hemipelagic to pelagic deposits between these carbonate highs, and (4) the Neogene to Recent siliciclastic succession of the Indus Fan, which essentially consists of very large scale channel-levee systems, filled with a considerable amount of coarse sediments (Figs. 3, 4).

The principal focus of this paper is one isolated carbonate platform of the Paleocene-Eocene interval (Fig. 4). These drowned isolated carbonate platforms are separated by a deeper water trough from the attached carbonate ramp and buried under a $1600 \mathrm{~m}$ thick basin floor fan system of the Offshore Indus Basin. This sedimentary package unconformably overlies the Late Cretaceous to Early Paleocene igneous complexes of the Deccan volcanics and has a conformable contact with the overlying thin sequence of deep marine shales. In deep water, the time equivalent succession appears as a condensed section and may be composed of mudstone or shales.

\section{Data and methods}

\section{Seismic and well data}

This study is based on the analysis of industrial 2D seismic data that was acquired and processed in 2002 for hydrocarbon exploration. The 160-fold seismic survey was recorded with SEG reverse polarity, where the increase in acoustic impedance is reflected as negative amplitude. Standard processing yielded data length ranges between 8 and $10 \mathrm{~s}$ with a $4 \mathrm{~ms}$ sampling interval. With a grid interval of approximately $5 \mathrm{~km}$ in each direction, the regional dataset covers an area between the continental shelf and the deep basin, with water depths ranging from $400 \mathrm{~m}$ to more than $3500 \mathrm{~m}$ (Fig. 1). Most of the seismic lines are concentrated over the buried isolated carbonate platforms of the Paleocene to Eocene succession (Fig. 5). The vertical seismic resolution is $18 \mathrm{~m}$ for a central frequency of $45 \mathrm{~Hz}$ and velocity $2000 \mathrm{~m} / \mathrm{s}$. Overall the quality of seismic imaging is good, but it compromised close to the volcanic basement and structural highs.

The seismic interpretation was conducted using Petrel software. Key reflections were identified and mapped on seismic data based on reflections discontinuity criteria. Further, data from three exploration wells (Pakcan-1, Indus Marine-A1, and Pak-G2-1) were incorporated to support the seismic interpretation. The time-depth relationship was established using VSP and check shot dataset. The well Pak-G2-1 was drilled in 2004 to test the hydrocarbon potential of the Paleocene-Eocene carbonate succession. It penetrated the approximately $2050 \mathrm{~m}$ thick Early Eocene to Pleistocene sedimentary sequence (Fig. 4). The stratigraphy from the wells Pakcan-1 and Indus Marine-A1, located on the present-day continental shelf (Figs. 1, 3), was extrapolated to the seismic dataset which provided a chronostratigraphic framework for the carbonate and the younger sedimentary succession. The well data consist of a standard wireline log suite comprising gamma ray (GR), sonic (DT), density, and neutron porosity. Furthermore, the biostratigraphic analysis of the drill cuttings brought additional dating constraints and depositional environment interpretation of the carbonate sequence.

The seismic stratigraphic framework was established using standard seismic stratigraphic interpretation techniques 


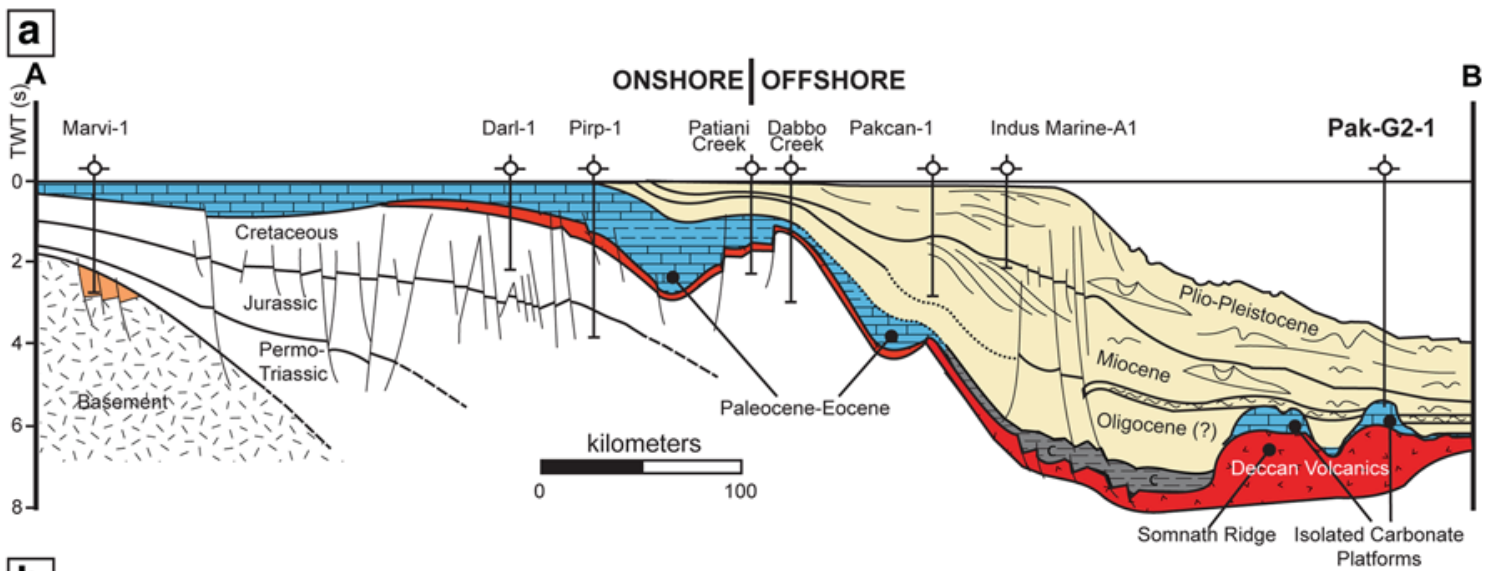

b

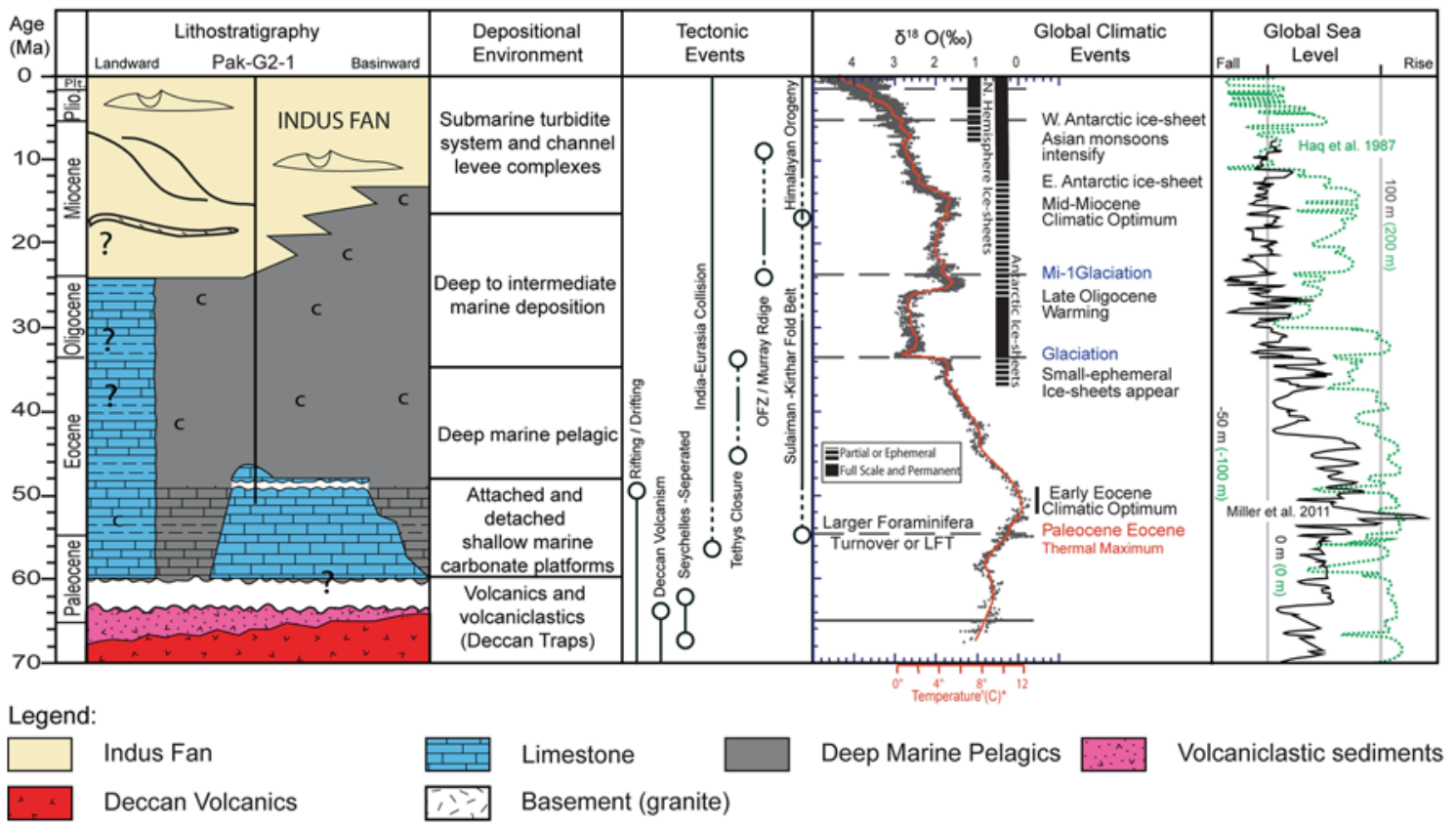

Fig. 3 a Regional cross-section of the Offshore Indus Basin and adjacent onshore basin, modified after Carmichael et al. (2009) (for location, see map in Fig. 2a). b Regional stratigraphic column of the Offshore Indus margin showing generalized stratigraphic relationship between studied carbonate platform and other stratigraphic successions drilled from the Eocene to recent. The location of well is shown

(Mitchum et al. 1977; Fontaine et al. 1987; Embry 1993). Depositional sequences in carbonate buildups are defined by unconformities and their correlative conformities as sequence boundaries. These sequence boundaries are based on reflection terminations (onlap, downlap, and truncation), erosional surfaces, truncations, and downlap events (Mitchum et al. 1977). The detailed mapping for the understanding of stratigraphic succession was achieved using advanced seismic interpretation techniques such as Horizon cube method by dGB OpendTect software (de Groot et al. 2010; Qayyum et al. 2012). This approach is used to produce densely mapped seismic sections and allow defining the HorizonCube in Fig. 1. Changes in depositional environment and regional tectonic events referred in the text are also indicated. On left side global deepsea oxygen and temperature curve with significant Cenozoic global climatic events is illustrated, modified after Zachos (2001), and compared with the global sea level curves (Haq et al. 1987; Miller et al. 2011)

density attribute, which helps to determine the intervals of reflection convergence (dense) and divergence (less dense). The convergence areas are mostly related to unconformities, condensed sections, reef tops, and flooding surfaces.

\section{Results and interpretation}

\section{Seismic facies}

Eight seismic facies are described from seismic profiles, differentiated by their internal reflection configuration 


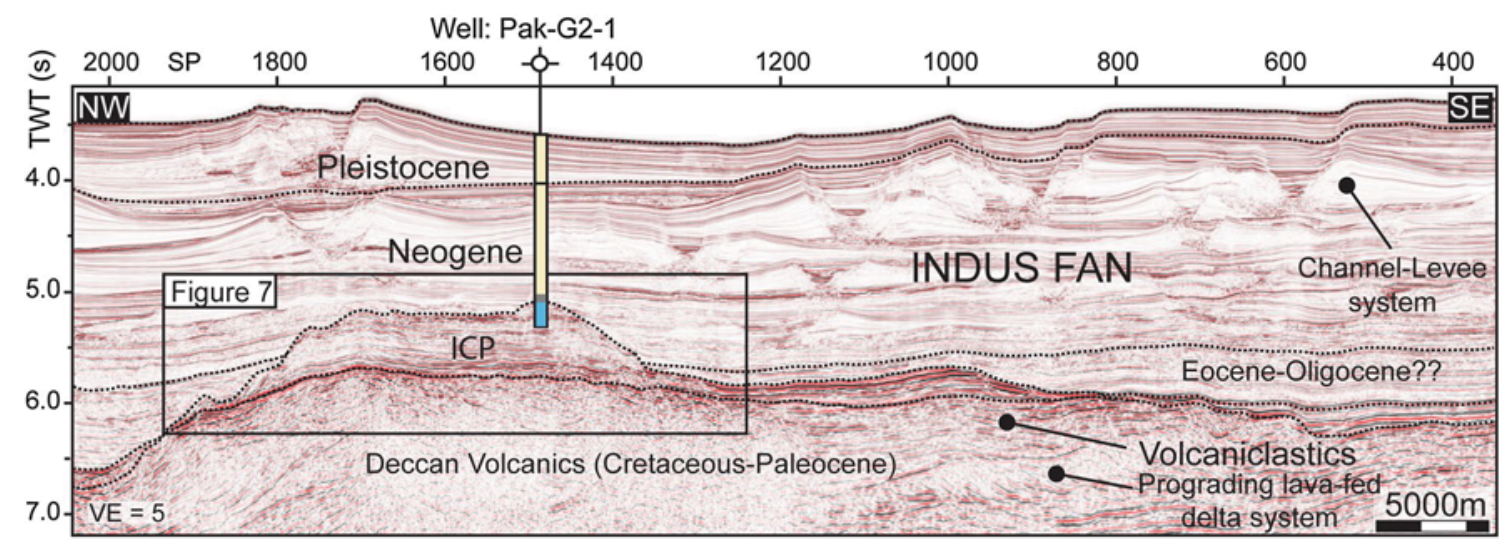

Fig. 4 Interpreted NW-SE oriented regional seismic profile showing the stratigraphic framework of the Paleocene-Eocene isolated carbonate platform (ICP isolated carbonate platform) (for location see map in Fig. 1)
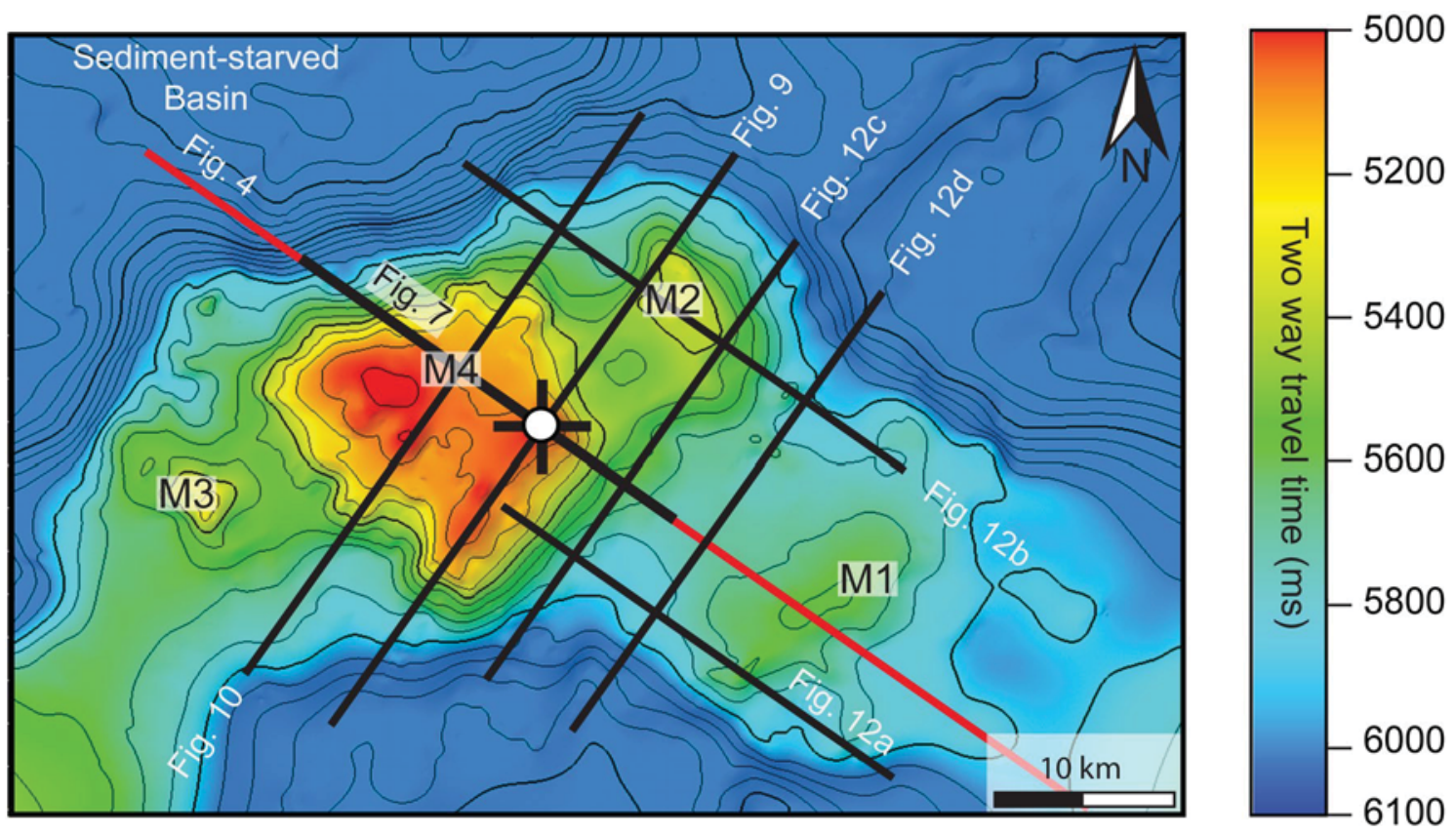

Well: Pak-G2-1 (Late Stage Buildup)

Fig. 5 Time structure map (two-way travel time) of the top surface of carbonate platform with position of seismic transects presented in this study. M1, M2, M3 and M4 are four carbonate buildups identified. Contour line interval is $100 \mathrm{~ms}$

and external geometry. The isolated carbonate platform is seismically characterized by medium- to high-amplitude reflections as compared to the younger siliciclastic deposits of the Indus Fan. The irregular top surface of the platform appears as a high-amplitude reflection, covering irregular and semi-continuous reflections with several parabolic shapes (Fig. 6a). This pattern is most likely produced by an intensive karstification, possibly with formation of caves at the platform top before its final demise. This irregular surface may be overlain by some patch reefs which in the data are imaged as pinnacle shaped bodies (Fig. 6a). The inner platform facies are characterized by medium- to highamplitude reflections with strong continuity and parallel relationship (Fig. 6b). This variance in reflection amplitude is interpreted as the alternating succession of a lagoonal to shallow marine environment. Reflections of these facies often have low-angle dips, thus forming localized packages with internal shingling. Often inner platform facies are laterally interrupted by the convex upward or bidirectional mound facies, having a high impedance contrast at the top 


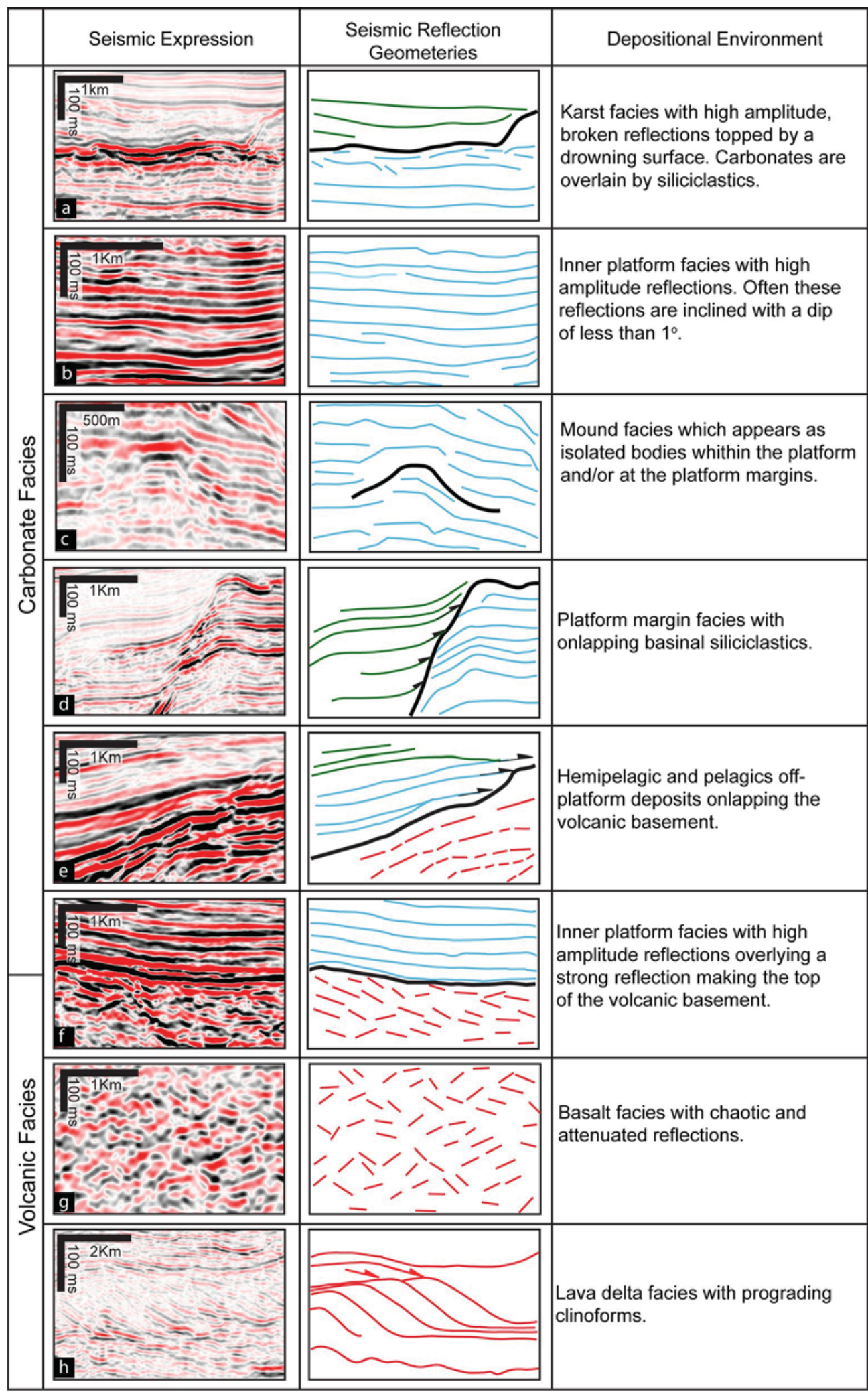

Legend:

Basalts

Carbonates

Siliciclastics

Fig. 6 Catalogue of seismic facies recognized in the high-resolution seismic dataset 

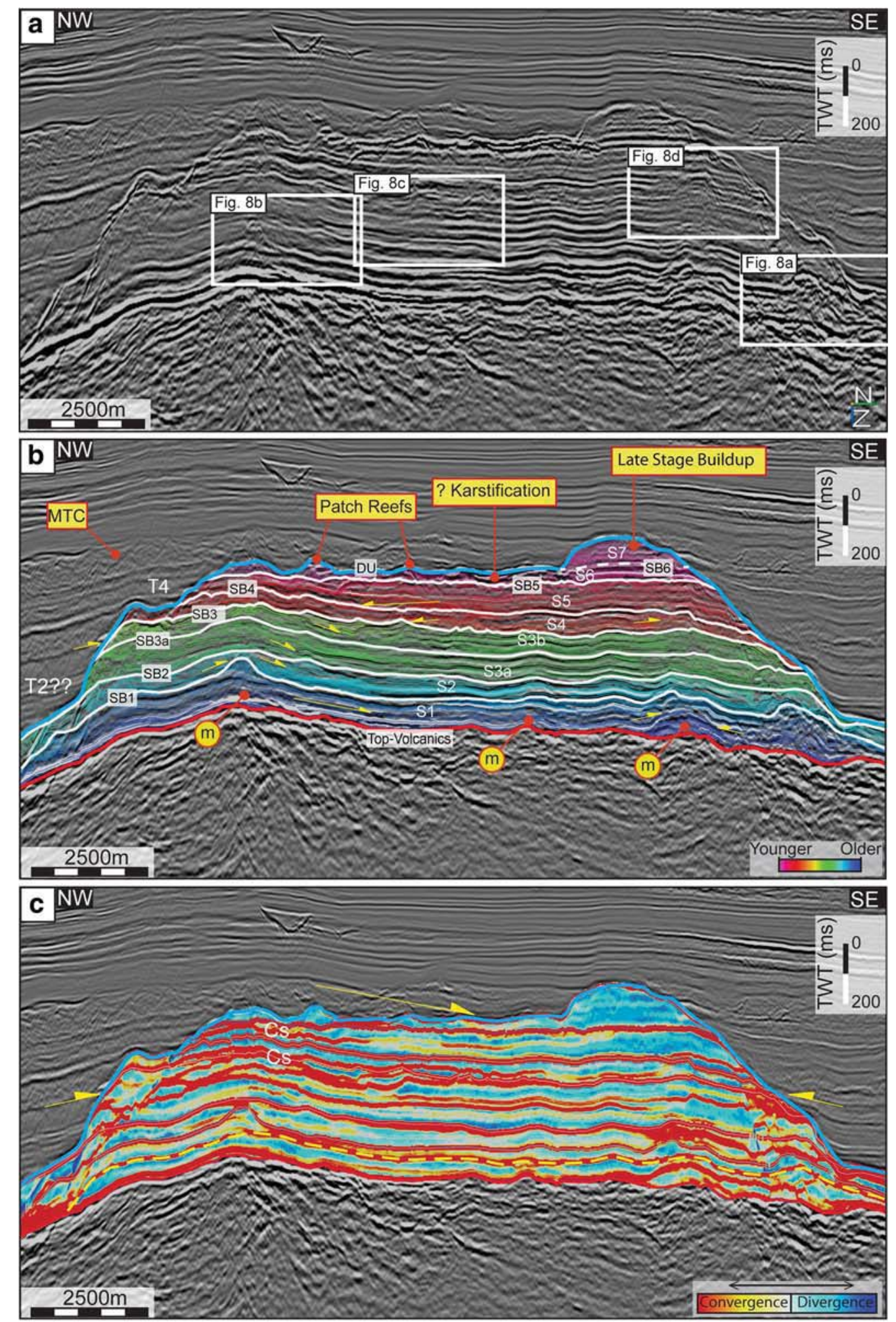

Legend:

Drowning Unconformity (DU)

Top Volcanics 
4Fig. 7 Seismic profile crossing the carbonate platform in a NW-SE direction. a Un-interpreted view. b Interpreted section of the M4 carbonate buildup with all seismic characteristics and seismic reflection configurations. MTC mass transport complex; $m$ mound facies; $S B$ sequence boundary. c Interpreted section of M4 carbonate buildup with horizon cube attribute and showing the region of convergence and divergence seismic of reflections patterns; $C s$ condensed section. The location of the seismic line is indicated in Fig. 5

(Fig. 6c), which is interpreted as an indication of the possible presence of reefs and mounds. The juxtaposition of the inner platform facies with the mound facies is proposed to represent the contact of inner platform deposits with reef and reef debris.

The slopes of the carbonate platform appear as sharp boundaries with the surrounding strata arranged in an onlap configuration (Fig. 6d). High- to medium-amplitude basinal and hemiplegics seismic facies are present basinward of the carbonate platform slopes and the toe of the slopes (Fig. 6e). The boundary between the carbonate and volcanic basement is sharp because of high acoustic impedance contrast between carbonate and volcanic rocks (Fig. 6f). The volcanic basement contains reflection-free seismic facies and chaotic reflections with low amplitude (Fig. 6g). At places, sigmoidal shaped reflections with high acoustic impedance contrast are imaged on the seismic data, which represent lava-fed delta systems comparable to those described by Jerram et al. (2009) in Faroe-Shetland Basin (Fig. 6h).

\section{Seismic stratigraphy}

Detailed analysis of seismic reflection configuration identified seven seismic stratigraphic units within the studied isolated carbonate platform based on stratal terminations, seismic reflection geometries, and stratal stacking patterns, bounded by key sequence stratigraphic surfaces (Figs. 7, 8, 9, 10; Table 1). The seismic survey is time migrated, and depth control is inadequate. Thus, the vertical scale and time structure maps are in two-way travel time (Fig. 11). The stratigraphic framework is summarized in Table 1, with each unit described below. The location of the seismic lines used for the stratigraphic subdivision is displayed in Fig. 5 in a time structure map.

\section{Deccan volcanics}

The Deccan volcanics form a chain of seamounts and guyots, dominated by basaltic flows with interlayered sedimentary packages (Carmichael et al. 2009). The top of the volcanics is defined by a strong seismic peak with a positive amplitude, which marks a pronounced regional subaerial unconformity at the Cretaceous-Paleogene boundary $(\mathrm{K}-\mathrm{Pg})$. Often the unit contains sigmoidal reflection bundles of the prograding lava basalt (Figs. 4, 6h). Apart from these features, this unit mostly includes the basalt facies with chaotic and attenuated reflections (Figs. 4, 6g). The thickness and nature of the volcanic unit are highly variable. Laterally, age equivalent rocks attributed to the Khadro Formation of the Ranikot Group were encountered in wells in the onshore areas of the Greater Indus Basin (Ahmad and Ahmad 2005). This unit has not been drilled until today in the studied area. However, its tentative age assignment is as old as Late Cretaceous to Early Paleocene (Calvès et al. 2008; Torsvik et al. 2013).

\section{Seismic unit S1}

Seismic unit S1 is the oldest sequence developed above Deccan volcanics with an onlapping reflection pattern and early transgressive mounds. Internally, this unit is dominated by high amplitudes and sub-continuous reflections, with frequent mound facies in the basal part (Figs. 7b, $9 b$ ). Toward the southeast, seismic frequency decreases in areas where the confined package consists of mixed chaotic reflections (Fig. 8a). This configuration indicates a complex assemblage of lithofacies that may range from volcaniclastic to shallow marine carbonates. Following the early transgressive event, a local prograding complex is observed, reflecting a normal regression (Figs. 7b, 8a). From the top, this unit is bounded by sequence boundary SB1.

In the map view, four distinct buildup areas are identified as M1, M2, M3, and M4 (Figs. 5, 11a). On the isochron map, the thickest interval is located in the eastern part of the volcanic ridge at the M1 buildup, which is considerably deeper and is the oldest succession of the carbonate platform (Fig. 11: S1). Thinning and onlapping of the unit toward the west suggest that the regions of M2, M3, and M4 were topographically higher during the deposition of the seismic unit S1. The maximum thickness represented by this unit is about $220 \mathrm{~ms}$ (TWT) on isochron map with an aerial extension of approximately $1700 \mathrm{~km}^{2}$.

\section{Seismic unit $S 2$}

Seismic unit S2 is characterized by a distinct reduction of the platform surface area and retreated margins (T1; Figs. 9b, 10b). It is a relatively thin unit with mostly medium- to low-amplitude reflections. In the lower part of the S2, some high amplitude and continuous seismic reflections are observed (Fig. 7b, c). These reflections sometimes onlap the top surface of S1 (SB1), forming a thinly defined basal transgressive package. The overall growth of this unit shows an aggrading stacking pattern. Often, subtle localized clinoforms are observed dipping towards the southeast and downlap onto the basal transgressive unit (Fig. 8b). 

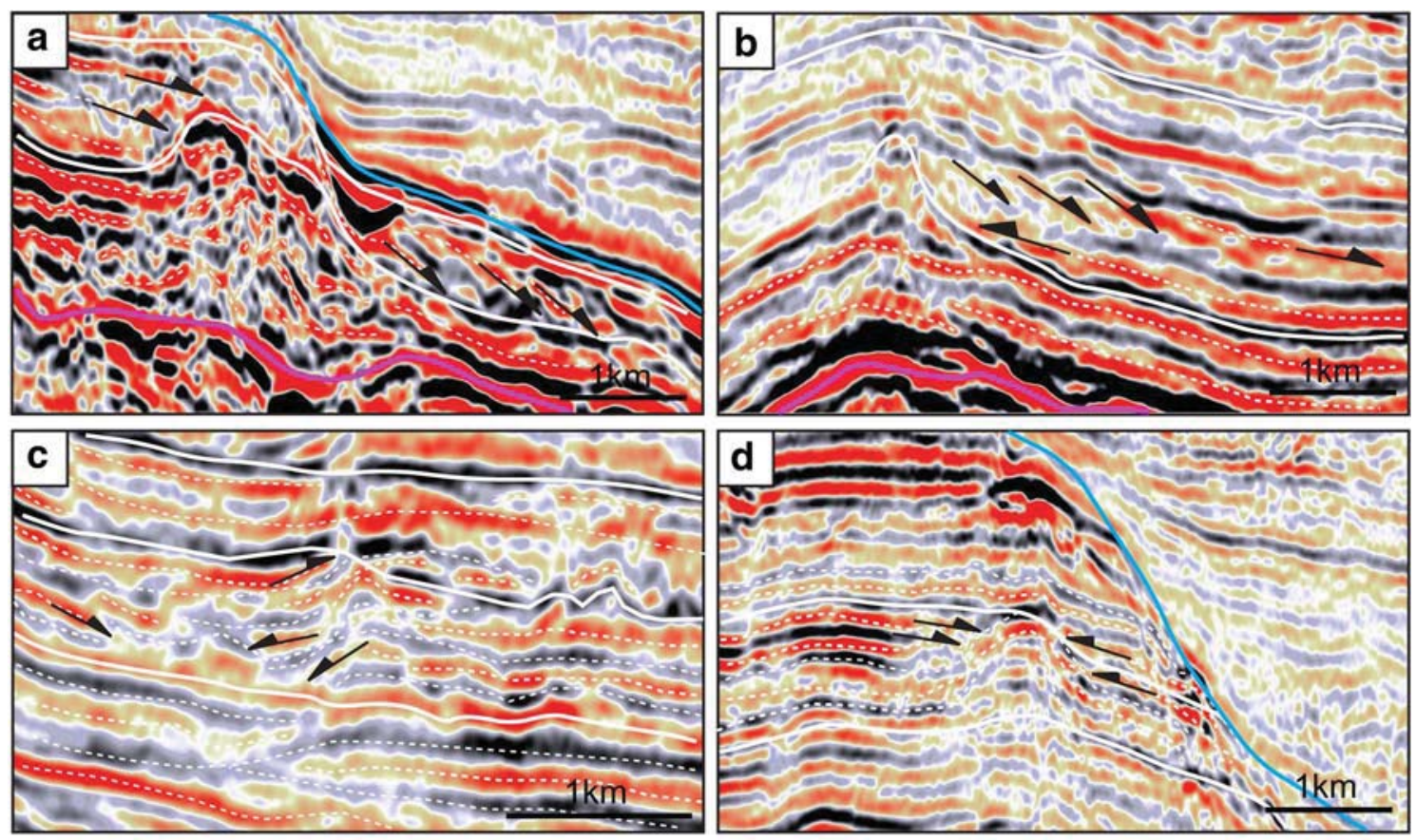

Legend:

Top Volcanics
$\square$ Stratal Terminations
$\square$ Drowning Unconformity (DU) $=$ Sequence Boundary (SB)

...... Reflection Geometry (Interpreted)

Fig. 8 Seismic characteristics of the M4 buildup a a confined chaotic reflection pattern. b Shingling reflections against the basal transgressive system. $\mathbf{c}$ Development of mound and shift in the depositional unit. $\mathbf{d}$ Mound facies in the margin

Numerous small mounds and pinnacles are observed within this unit (Fig. 12). The top of this unit is identified by a high-amplitude surface with an irregular relief, defined as horizon SB2 (Figs. 7, 9, 10).

Overall, this unit is thin in the middle part of the carbonate platform, across the buildup M4. It is thicker along the northeastern and southwestern margins of the platform, identified as buildups M2 and M3, respectively (Fig. 11). During the formation of this unit, M1 buildup area is consistently the thinnest, with small patches and mound facies. The total surface area covered by this unit is ultimately limited to about $1315 \mathrm{~km}^{2}$, with a maximum thickness of less than $200 \mathrm{~ms}$.

\section{Seismic unit S3}

Seismic unit S3 conformably overlies the unit S2. The facies in the lower part are analogous to the seismic unit $\mathrm{S} 2$, whereas the upper part shows high amplitude, subparallel, continuous seismic reflection patterns with subtle clinoforms toward the central platform, forming a condensed section to the west (Figs. 7c, 8c). Often, some onlaps and in-fills are partially truncated at the top of this unit (Fig. 8c). Several mound facies with chaotic reflection and terminations are observed (Fig. 9b). The platform margin facing the open ocean retreated and developed a terrace that was around $850 \mathrm{~m}$ in width (T2), whereas the eastward margin exhibits a continuous aggrading stacking pattern (Figs. 9, 10). The top of this unit is delimited by SB3, which is imaged as a high-amplitude continuous surface.

An isochron map of this unit reveals a remarkable upward growth with a maximum relief of around $200 \mathrm{~ms}$ (TWT) and steepening of the platform margins by more than $15^{\circ}$. The thickest interval lies in the center of the platform, at the location of buildup M4 (Fig. 11b: S3). A distinct succession characterized by strong reflections with hummocky to chaotic pattern piles up as off-platform deposits between these buildups.

\section{Seismic unit $S 4$}

S4 is mainly characterized by medium amplitude, wavy, and semi-continuous seismic reflections with minor lateral facies changes. The lower part of the unit onlaps onto SB3, forming a wedge-to-sheet-like body which thins out toward the northwest (Fig. 7b, c). Within this unit, two bodies with convex upward reflections and bidirectional downlaps are interpreted as the mound seismic facies, which are separated 

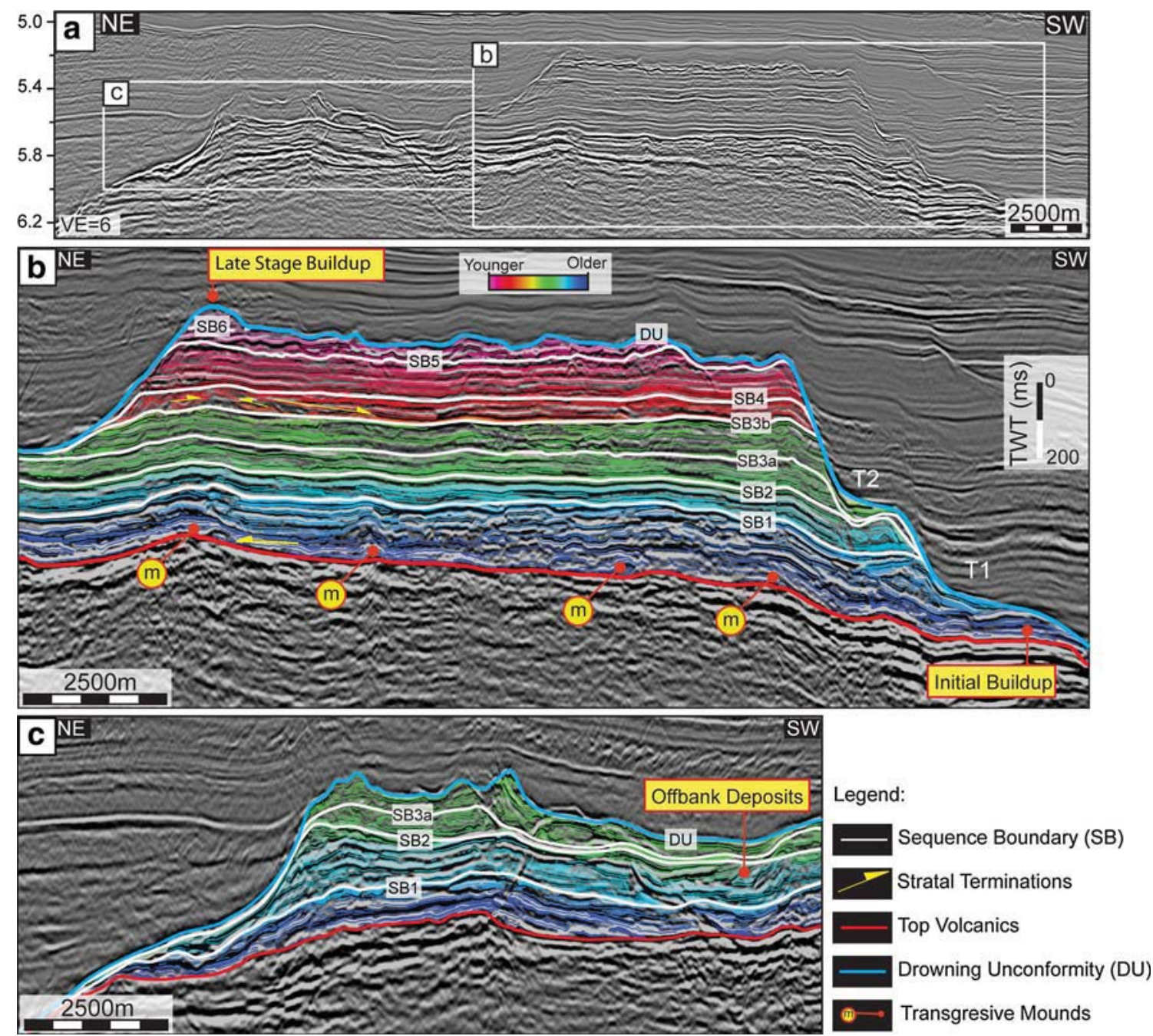

Fig. 9 a NE-SW trending seismic profile across the central part of the platform (see map in Fig. 1 for location). b and $\mathbf{c}$ are interpreted seismic section of the M4 and M2 buildups, respectively

from each other by the inner platform facies (Figs. 8d, $9 \mathrm{~b}, 10 \mathrm{~b})$. These mounds measure around $70 \mathrm{~ms}(\mathrm{TWT})$ in height and 550-650 $\mathrm{m}$ in width (Figs. 8d, 9b, 10b). Unit S4 is bounded at the top by the sequence boundary SB4.

In contrast to the seismic unit $\mathrm{S} 3$, this unit marks a significant change in a deposition. In this unit, the main thickness lies at the southeastern margin of the buildup M4. The unit thins toward the northwest with mound facies on the top. The average thickness of this unit is less than $100 \mathrm{~ms}$ (TWT) with a maximum surface area of about $350 \mathrm{~km}^{2}$ (Fig. 11b: S4).

\section{Seismic unit S5}

With seismic characteristics similar to those of S4, seismic unit S5 is a wedge-shaped unit becoming thinner toward the northwestern margin of the platform, passing from about $120 \mathrm{~ms}$ to about $40 \mathrm{~ms}$ (TWT) (Figs. 7b, $11 \mathrm{~b})$. Its basal part onlaps over the inclined surface of SB4 since the unit is thinner toward the northwest margin. In contrast, this unit shows an average thickness of approximately $120 \mathrm{~ms}$ on the seismic profiles oriented northeast to southwest (Figs. 9b, 10b). Reflection amplitude is moderate, and reflection continuity is low to high, with decreasing frequency toward the northwestern margin. At the eastern margin, the internal reflections are conformably overlying SB4. Internally, this unit displays mostly sigmoidal clinoforms prograding to the west. At the western margin, there is a terrace of around $1000 \mathrm{~m}$ in width (T4: Fig. 7b). The top surface of unit S5, identified as SB5, is a relatively flat surface. 

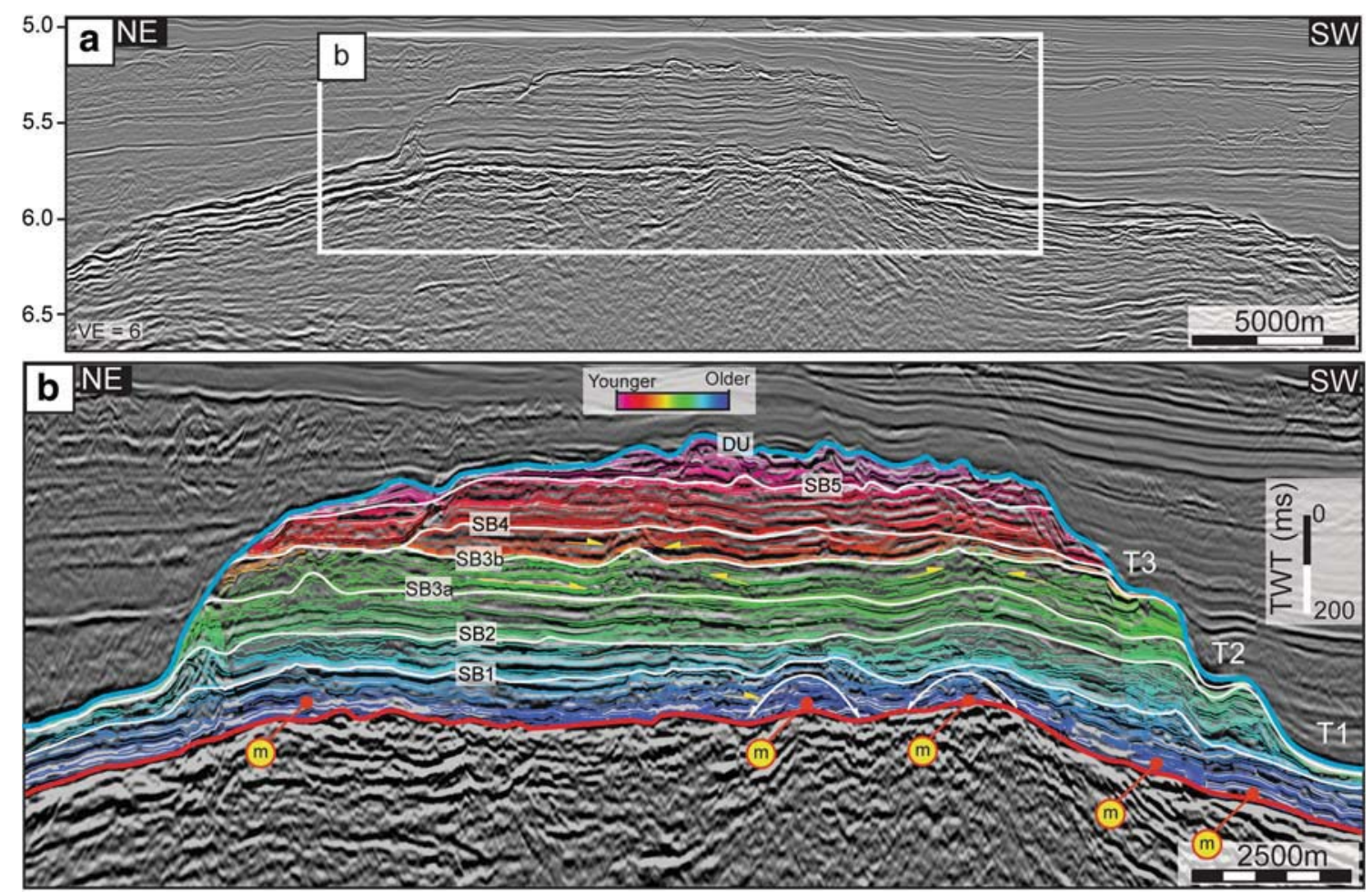

Legend:

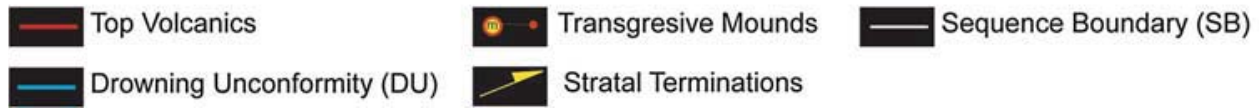

Fig. 10 a NE-SW trending seismic profile across the central part of the platform (see map in Fig. 1 for location). b Interpreted section of M4 buildup

\section{Seismic unit S6}

Seismic unit S6 is mainly characterized by medium- to high-amplitude and discontinuous seismic reflections. High-amplitude continuous and parallel seismic facies are confined to the east margin of the carbonate buildup (Figs. 7, 9). This unit is bounded on the top by a highamplitude uneven surface, picked as a regional unconformity across the platform with mounds and troughs (Fig. 7b). However, this surface becomes continuous and smooth toward the eastern margin of the buildup, where it marks the onset of the late-stage buildup-seismic unit S7.

On isochron maps, seismic unit S6 restricted to a surface area of approximately $260 \mathrm{~km}^{2}$. The maximum thickness is about $60 \mathrm{~ms}$ in average, which separated the buildup M4, from the late-stage buildup.

\section{Seismic unit $S 7$}

Seismic unit S7 is the youngest unit of the carbonate platform and consists of a convex upward late-stage buildup (Figs. 7, 9). This unit is located and restricted to the southeastern side of the underlying M4 buildup and consists mostly of medium- to low-amplitude with semi-continuous to parallel seismic reflections. The internal geometries of the late-stage buildup, with a mostly aggrading growth pattern, are coupled with retrograde margins (Fig. 7b). At the top, this unit is bounded by a strong-peak surface, interpreted as drowning unconformity, which marks the cessation of carbonate platform growth in the analyzed dataset. This unit covers an area of less than $8 \mathrm{~km}^{2}$, the maximum thickness of which is approximately $80 \mathrm{~ms}$ as mapped on the seismic profile (Fig. 7).

\section{Calibration with biostratigraphy}

Cutting samples from the well Pak-G2-1 were investigated for the facies and the microfaunas of the carbonate platform (Fig. 13). The well-penetrated $\pm 320 \mathrm{~m}$ of shallow water carbonates, encompassing seismostratigraphic units S5, S6, and S7 (Fig. 14). Biogenic components are dominated by larger benthic and small benthic foraminifera, planktonic foraminifera, gastropods, and brachiopods with some siliciclastic rock fragments. Further detailed investigation of the 
Table 1 Description of the seismic units

\begin{tabular}{|c|c|c|c|c|}
\hline Seismic units & Top surface & Identification criteria & $\begin{array}{l}\text { Maximum thickness (TWT) } \\
\text { amplitude }\end{array}$ & Intraplatform facies \\
\hline S7 & DU & $\begin{array}{l}\text { Seismic; drill cutting and log } \\
\text { character }\end{array}$ & $\begin{array}{l}T=80 \mathrm{~ms} \\
\text { Medium amplitude, continuous } \\
\text { reflections }\end{array}$ & Aggrading late-stage buildup \\
\hline S6 & SB6 & $\begin{array}{l}\text { Seismic and log character, and } \\
\text { drill cuttings }\end{array}$ & $\begin{array}{l}T=60 \mathrm{~ms} \\
\text { Medium to high amplitude } \\
\text { Discontinuous to chaotic }\end{array}$ & $\begin{array}{l}\text { Chaotic and discontinuous reflec- } \\
\text { tions }\end{array}$ \\
\hline S5 & SB5 & $\begin{array}{l}\text { Seismic and log Character drill } \\
\text { cuttings }\end{array}$ & $\begin{array}{l}\mathrm{T}=120 \mathrm{~ms} \\
\text { Medium amplitude } \\
\text { Continuous to semi-continuous }\end{array}$ & $\begin{array}{l}\text { Progradation, thickness decreases } \\
\text { towards northwest. }\end{array}$ \\
\hline S4 & SB4 & Seismic character & $\begin{array}{l}\mathrm{T}=100 \mathrm{~ms} \\
\text { Low amplitude and semi-contin- } \\
\text { uous }\end{array}$ & $\begin{array}{l}\text { Mostly progradation and onlapping } \\
\text { on the base surface }\end{array}$ \\
\hline S3b & SB3 & Seismic character & $\begin{array}{l}\mathrm{T}=100 \mathrm{~ms} \\
\text { High amplitude, parallel to sub- } \\
\text { parallel and continuous }\end{array}$ & $\begin{array}{l}\text { Aggrading facies minor prograda- } \\
\text { tion towards north-northwest }\end{array}$ \\
\hline S3a & SB3a & Seismic character & $\begin{array}{l}T=100 \mathrm{~ms} \\
\text { High amplitude, parallel to sub- } \\
\text { parallel and continuous }\end{array}$ & $\begin{array}{l}\text { Aggrading and progradational } \\
\text { facies south to southeast }\end{array}$ \\
\hline $\mathrm{S} 2$ & SB2 & Seismic character & $\begin{array}{l}T=200 \mathrm{~ms} \\
\text { High to low amplitude, continuous } \\
\text { to discontinuous }\end{array}$ & $\begin{array}{l}\text { Aggrading basal part with localized } \\
\text { progradation towards the south to } \\
\text { southeast }\end{array}$ \\
\hline S1 & SB1 & Seismic character, interval velocity & $\begin{array}{l}T=220 \mathrm{~ms} \\
\text { High amplitude discontinuous } \\
\text { reflections }\end{array}$ & $\begin{array}{l}\text { Aggrading, backstepping and } \\
\text { progradation }\end{array}$ \\
\hline Deccan volcanic & Top volcanics & Seismic character, interval velocity & $\begin{array}{l}\text { Seismic dipping reflection (inner } \\
\text { and outer SDRs) }\end{array}$ & $\begin{array}{l}\text { Reflection free, sometime with pro- } \\
\text { grading and high amplitude facies }\end{array}$ \\
\hline
\end{tabular}

samples coupled with well logs and seismic interpretation leads to the following results.

Samples from $4750 \mathrm{~m}$ to $4630 \mathrm{mMD}$ (meters-measuring depths) depth correspond to the upper part of the seismic unit S5 that predominantly consists of creamy-white fossiliferous limestone with abundant benthic foraminifera and some other bioclasts. The abundance of larger benthic foraminifera, which are represented by Lokhartia (Fig. 13a, b), Alveolina (Fig. 13c, d), Nummulites (Fig. 13e, f, k), Operculina, and Orbitolites in the absence of planktonic specimens is taken as an indication of shallow, open marine to inner neritic environment. In conjunction with the cuttings samples, the wireline log characters show a rather clean carbonate succession. The GR log displays lowamplitude response of less than 45 API (Fig. 14), indicating a lack of any argillaceous materials with minor heterogeneity (Lucia 2007). The estimated average porosity ranges between 20 and $30 \%$, with a bulk density of about $2.3 \mathrm{~g} /$ $\mathrm{cm}^{3}$. The upper bounding surface 'SB5' coincides with relatively high GR log values (greater than 50 API). However, there is a slight mismatch between the wireline log and seismic data, attributed to the poor depth control $( \pm 5 \mathrm{~m})$.

On the depth scale, seismic unit ' $\mathrm{S} 6$ ' ranges between 4630 and $4530 \mathrm{~m}$. It is mainly composed of wackestone to packstone and is rich in benthic foraminifera such as Nummulites (Fig. 13e, f) (N. atacicus, N. globulus) Alveolina sp., Assilina sp. (Fig. 13h), and miliolids (Fig. 13i). In the well log suite, the GR facies shows serrated low- to medium-amplitude values of around 45 API to 39 API in the basal part of the unit. Uphole, the log shows an increase in the values to up to $65 \mathrm{API}$, and then a decrease again to 51 API at the SB6. The DT and density logs also show the similar features, varying between 60 and $100 \mu \mathrm{s} / \mathrm{ft}$. and $2.0-2.3 \mathrm{~g} / \mathrm{cm}^{3}$, respectively. Similarly, the average porosity is $20-25 \%$, but values vary highly between 10 and $30 \%$ (Fig. 14). The variations observed in the log suite correlate to the high-amplitude reflection and chaotic seismic facies. These features are interpreted to represent a secondary porosity developed due to the dissolution and leaching of the formation during subaerial exposure and karstification (Fig. 14). Therefore, it is proposed that the top surface of the unit is a subaerial unconformity.

Seismic unit S7 corresponds to the late-stage buildup, which was penetrated between $4530 \mathrm{~m}$ and $4433 \mathrm{mMD}$. Below $4505 \mathrm{mMD}$, this unit is dominated by bioclastic packstone to grainstone. The succession contains fragments of litho- and bioclasts with the large benthic foraminifera Glomalveolina lepidula, Alveolina 

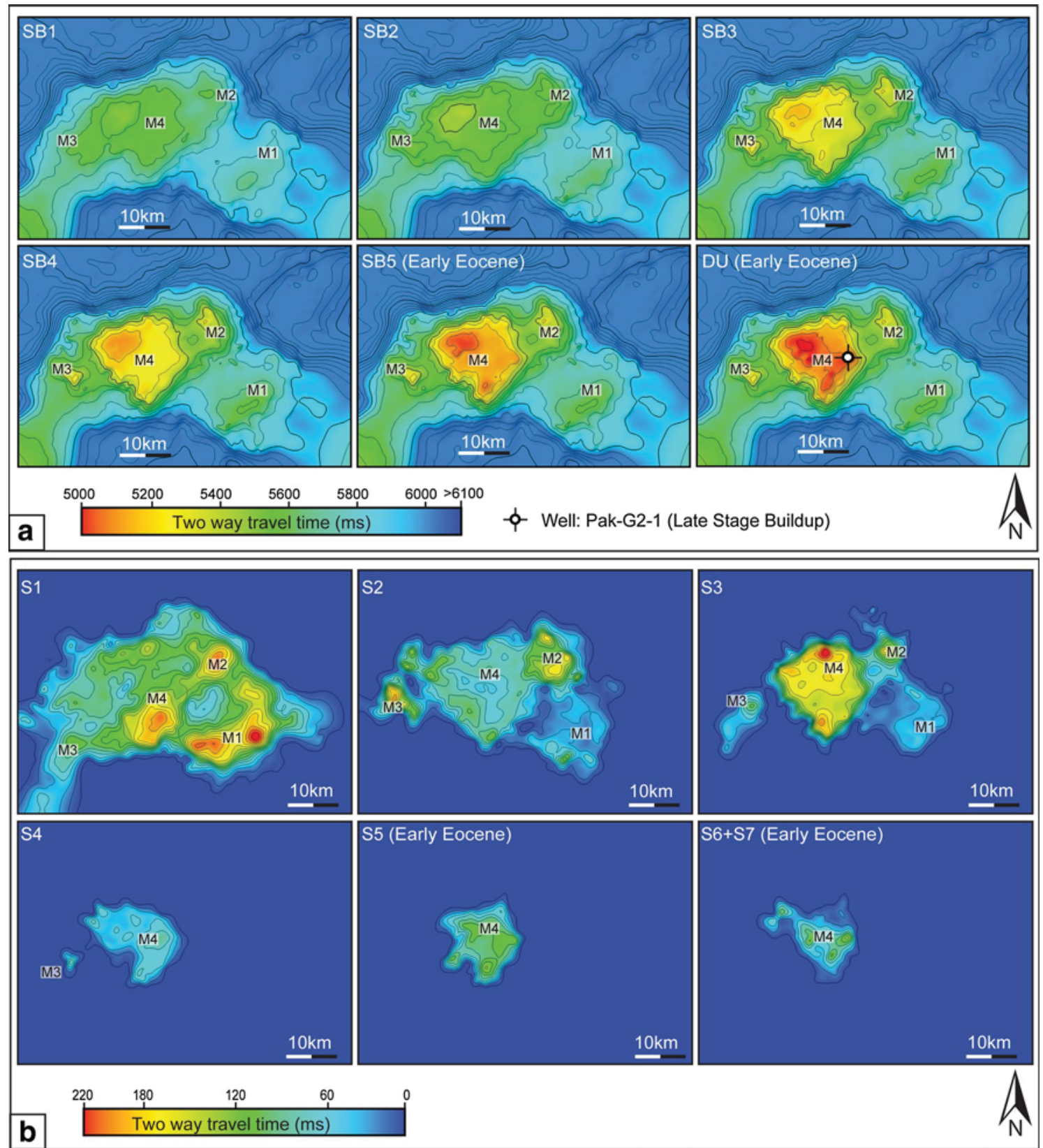

Fig. 11 a Time structure maps of the interpreted stratigraphic surface (SB1-DU) described in the study. M1, M2, M3 and M4 are four carbonate buildups identified in the isolated carbonate platform. The well Pak-G2-1 is located on the late-stage buildup. Contour lines are every $100 \mathrm{~ms}$ (thin black lines) and $500 \mathrm{~ms}$ (thick black lines).

sp., Orbitolites sp., and Nummulites sp. together with some small miliolids. Overall, in this unit, fossil shells are often recrystallized, and, therefore, the preservation of fossils is poorer as compared to the older units. This deterioration in preservation points towards postdepositional fluid migration and dissolution. Planktonic foraminifera replaces this assemblage in the upper part of this unit. At a depth of $4450 \mathrm{mMD}$, a mixture b Isochron maps which represent the two-way travel time thickness maps calculated by the thickness difference between top and bottom bounding surface of each seismic stratigraphic unit. Area with zero thickness is depicted as blue color

of deep marine sediments with shallow marine carbonate is noticed. The ratio of gray shale to carbonate sediments increases toward the top of platform implying a deepening of the environment. This is confirmed by a fining upward sequence in the GR $\log$ (Fig. 14). The average density of the formation is about $2.3 \mathrm{~g} / \mathrm{cm}^{3}$. Just $2 \mathrm{~m}$ below the top of the drowning unconformity-at a depth of $4335 \mathrm{mMD}$ - the collected samples are rich in 

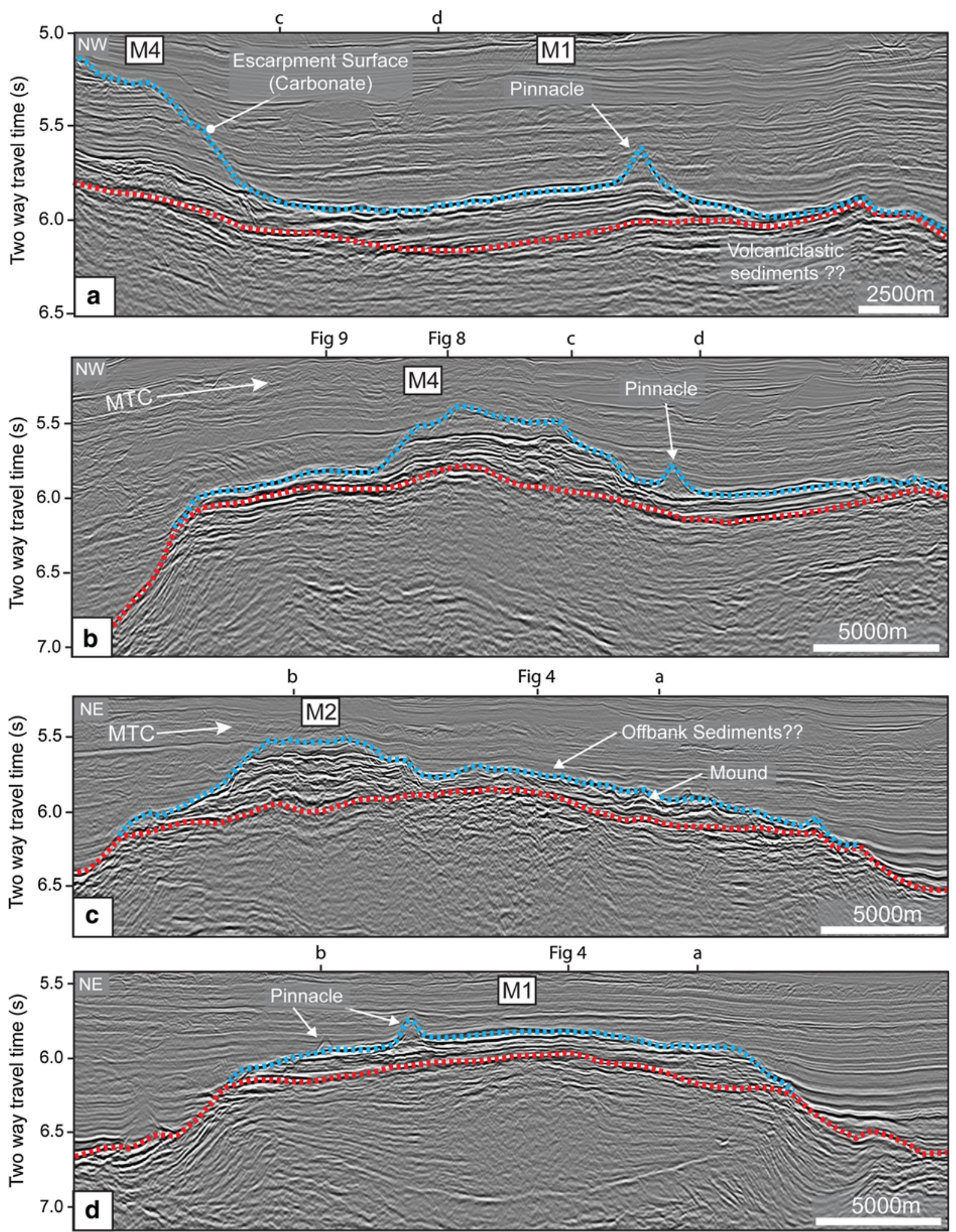

Legend:

….... Drowning Unconformity (DU) ….... Top Volcanics

Fig. 12 Seismic characteristics of the isolated carbonate platform. MTC mass transport complex (see Fig. 5 for seismic line positions) 

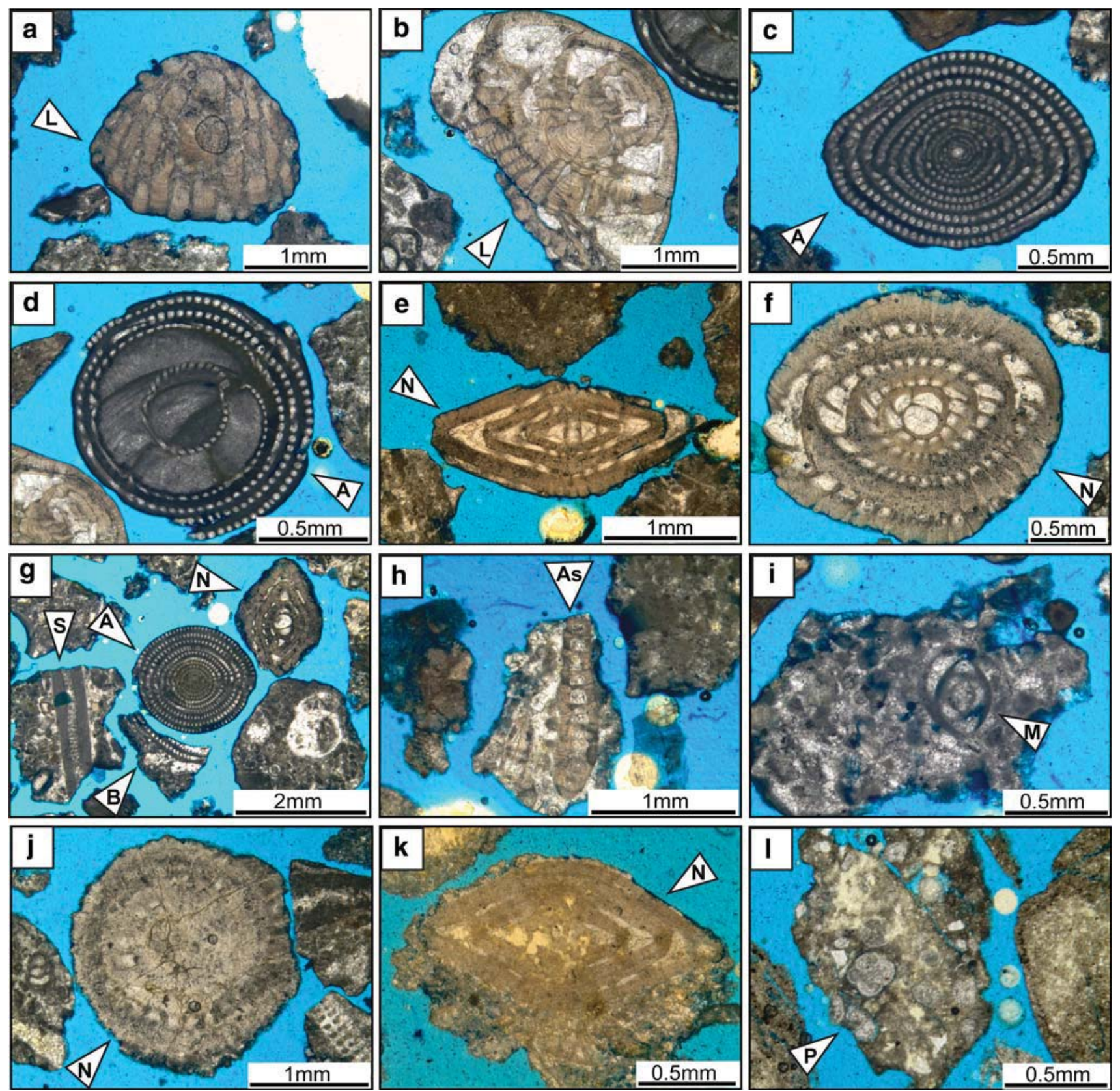

Fig. 13 Biostratigraphically significant larger benthic foraminiferas from Late Paleocene to Early Eocene. a, b Lokhartia sp., $(L)$, c Alveolina sp., (A) (axial section), d Alveolina sp., (A), (equatorial section), e Nummulites sp., ( $N$ ) (axial section), f Nummulites sp., $(N)$ (equatorial section), $\mathbf{g}$ bioclasts $(B)$ and some Eocene larger benthic

planktonic foraminifera and benthic species are entirely absent. The age-diagnostic planktonic species identified are Catapsydrax sp. and Globigerinatheka sp. (Wade et al. 2011). On the GR and DT, a gradual increase in the basal part of the unit is noticed (Fig. 14). This pattern is followed by the serrated values, which again decrease toward the interpreted drowning unconformity foraminiferas (Somalina sp., S), h a broken piece of Assilina sp., (As), i Milliolid foraminifera, $(M)$, in lithoclast, $\mathbf{j}$, k Nummulites sp., with poor preservation, $\mathbf{l}$ a lithoclast with abundant planktonic foraminiferas $(P)$

(DU), recognized at $4433 \mathrm{mMD}$ (Fig. 14) on the digital well logs motifs. In the GR and DT logs, a sudden lowto the high-amplitude pattern is observed along the shale/ carbonate boundary. The GR log jumped from 50 API below to around 130 API above. The same trend appears in DT and density logs, which seem to have increasing values. At $4320 \mathrm{mMD}$ depth (at $13 \mathrm{~m}$ above the DU), the 


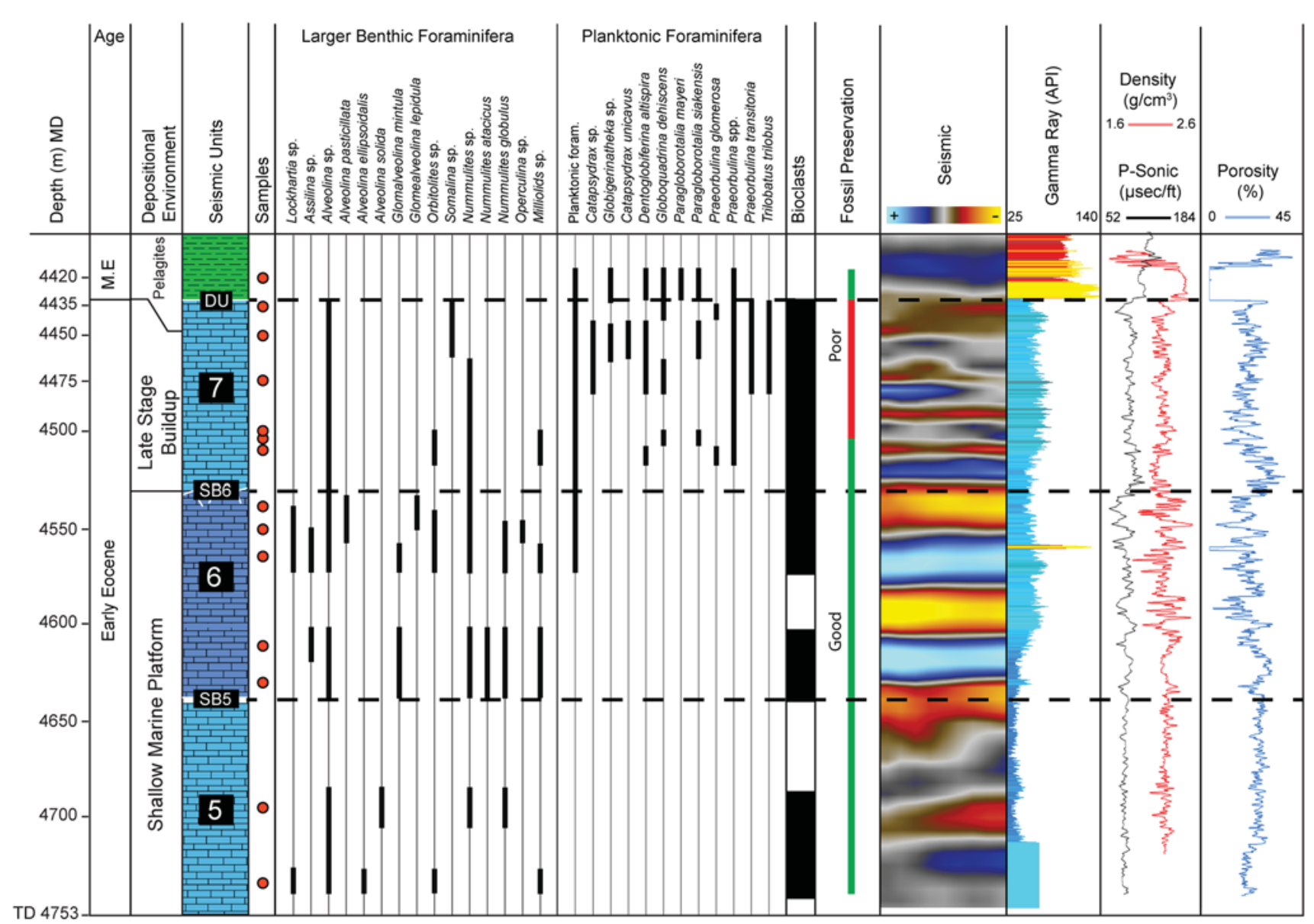

Fig. 14 Stratigraphic ranges of some important foraminiferal species in the studied section of well Pak-G2-1 and their corresponding seismostratigraphic units on depth converted seismic. The gamma ray

curve increasing from left to right. The black and red well curves are compressional sonic and density logs, respectively

assemblage is rich in age-diagnostic planktonic fossils with predominantly pelagic mudstone or marine shales. Some lithoclasts are also present.

\section{Discussion}

\section{Paleoecology and biostratigraphy}

The large benthic foraminiferal assemblages indicate that the carbonate succession accumulated in a tropical environmental setting under oligotrophic conditions (Hallock and Glenn 1986; Jorry et al. 2006). The large benthic foraminifera together with the planktonic foraminifera allow an age assignment of the carbonate platform. For the age model, the work of Serra-Kiel et al. (1998) on larger benthic foraminifera biozones was applied together with the documented stratigraphic distribution of these fossils in the Greater Indus Basin by Afzal et al. (2009, 2011).

The earliest appearance of Lokhartia sp. is documented as SBZ3 (Serra-Kiel et al. 1998) which extends into the Early Eocene age in the region of the eastern Tethys (Akhter and Butt 1999; Afzal et al. 2009, 2011). The first appearance of Alveolina sp. marks the biozone SBZ5/6 at the base of the Eocene (Hottinger 1971; Serra-Kiel et al. 1998). However, the analyzed samples were void of common large benthic foraminifera of SBZ3 and SBZ4 Zones in the Greater Indus Basin (Afzal et al. 2011), such as Ranikothalia and Miscellanea. Therefore, the presence of Lokhartia sp. and Alveolina sp. together suggests an earliest Eocene age for the shallow marine carbonate platform (Fig. 14), equivalent to Zone SBZ5/6 by Serra-Kiel et al. (1998). Later, the first appearance of Nummulites atacicus and Nummulites globulus is attributed to the Zone SBZ8. These results are consistent with the biostratigraphic assemblage of other Tethyan carbonate platforms (Afzal et al. 2011). This foraminiferal assemblage indicates that this carbonate unit dates to an Early Eocene age. 
Fig. 15 Schematic model of the studied isolated carbonate platform. a Initial establishment and start-up phase. Carbonate platform deposition first began as mounds and patches at the top of the submerged volcanic high with early transgression. b The development of low relief platform with low-angle flat-top surface. c Carbonate platform retreated from the margins and catch-up with the relative sea level rise. M4 buildup accumulated vertically and M2 buildup subsequently drowned. d A fall in relative sea level was recorded and erosional features were formed. $\mathbf{e}$ The quick rise in sea level caused the terminal drowning of carbonate platform with subsequent formation of late-stage buildup in Early Eocene. The deep water settings were prevailed and pelagic continuous to develop till Middle Miocene when carbonate platform was covered by the terrigenous succession of Indus Fan
$<\mathrm{NE}$

$\underline{\mathrm{SW}}$

E. Late Stage Buildup and Final Drowning Stage (Early Eocene to Middle Eocene)

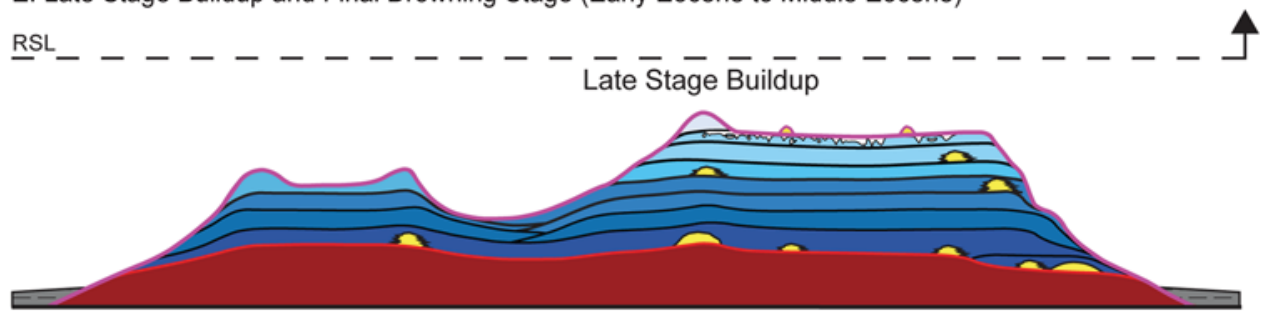

D. Subareal Exposure (Early Eocene)

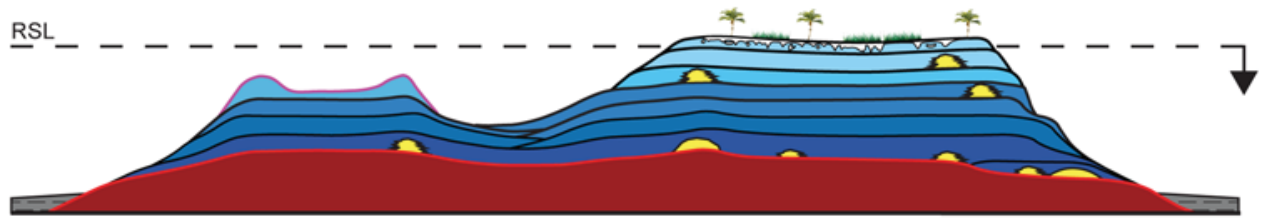

C. High Relief and Partial Drowning (Early Eocene)

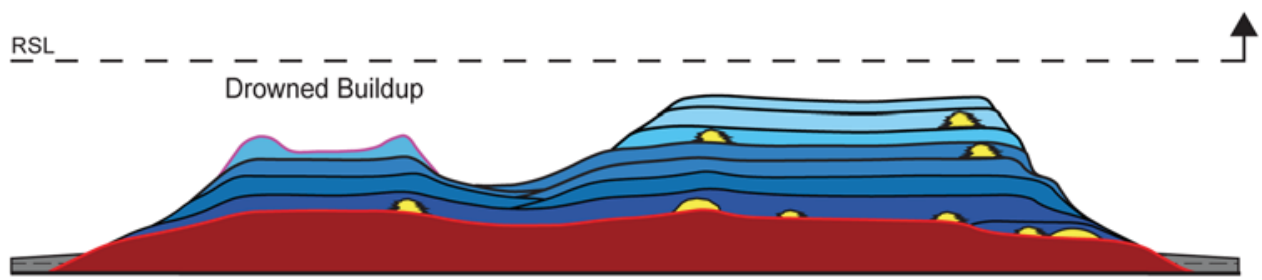

B. Low Relief Platform Stage

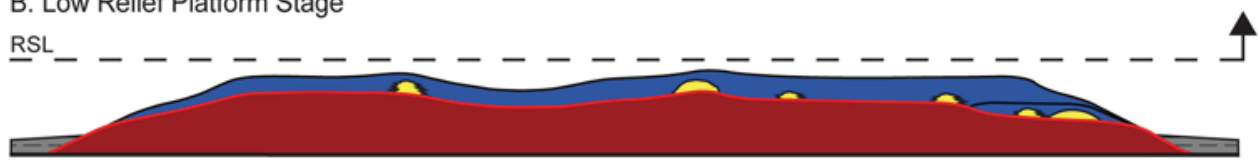

A. Initiation Stage

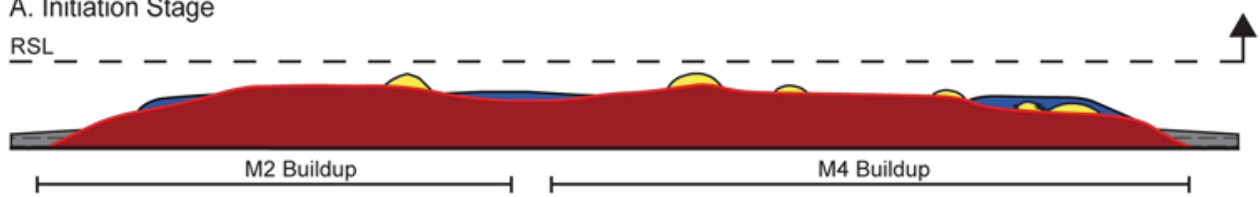

Legend:

$\square$ Top Volcanics $\square$ Drowning Unconformity (DU) $\square$ Sequence Boundary (SB) W- Karst

\begin{tabular}{|c|}
\hline Deccan Pelagics: \\
\hline
\end{tabular}

The final drowning event of the carbonate platform is placed in the interval encompassing the Early Eocene to earliest-Middle Eocene ( 49 to $\sim 45 \mathrm{Ma})$ by considering the appearance of the age-diagnostic planktonic foraminifera Catapsydrax sp. and Globigerinatheka sp. as evidence (Berggren 2005; Wade et al. 2011). Hence, the stratigraphic data of Calvès et al. (2008) proposing the platform drowning age as $37 \mathrm{Ma}$ are evidently challenged.

\section{Platform evolution}

Regional seismic interpretation and the biostratigraphy indicate that the carbonate platform has evolved during the Paleocene to Early Eocene times. Seismic stacking patterns, platform architecture, and depositional facies allow the identification of three-platform evolution stages-platform initiation stage, development of aggrading and escarpment stage, and late-stage buildup and drowning stage. 


\section{Platform initiation stage (S1-S2)}

Investigation of seismic profiles and isochron maps depict an atoll-shaped flat-topped volcanic complex. The evidence of subaerial exposure of this volcanic complex is a debatable subject. Subsequent localized growth of carbonates on the volcanic complex is evident in the data presented herein. These carbonates formed small mounds and patches which are interpreted as the first recognizable flooding event of the volcanic complex (Fig. 15a). This initial stage of carbonate development is interpreted as a startup to catch-up phase, which mostly forms the lower part of the seismic unit $\mathrm{S} 1$. This phase, with a backstepping of the mounds, seems to match with the global Early to Middle Paleocene sea level rise (Miller et al. 2011). During the further growth of this unit, carbonate production expanded and localized patches and mounds coalesced, thus forming a low relief flat-topped platform with small mounds and four distinct buildups areas M1, M2, M3, and M4.

Following the seismic unit 1 , the carbonate factory kept up with a significant local growth. This episode is marked by the presence of subtle clinoforms away from the mound observed in the seismic unit S1 (Fig. 7b) and interpreted as a localized lowstand on the carbonate platform which was later onlapped by a transgressive event of the seismic unit $\mathrm{S} 2$. This growth phase culminated with the drowning of the M1 buildup, which restricted the growth of neritic carbonates to the western margin of the volcanic ridge (Fig. 11b: S1). Several small mounds and pinnacles are present in the central and peripheral areas above the sequence boundary SB1. At the end of this stage, the carbonate platform developed a low relief with an estimated height of almost approximately $450 \mathrm{~m}$ (velocity $4500 \mathrm{~m} / \mathrm{s}$ ) and slope angles of less than $10^{\circ}$.

\section{Aggrading and escarpment stage (S3-S6)}

With a subsequent relative sea level rise, the carbonate platform significantly aggraded until the mid of the seismic unit 3 (SB3a). During this time, the platform margin retreated inwards, which is taken as an indication of insufficient carbonate production to fill up the available accommodation space, giving way to a 'give-up' sequence. With the onset of the seismic unit $3 b$, a significant shift in the depositional trend is observed. The trend marks a subtle intraplatform prograding complex towards the NW and may, in fact, be the downlapping on the underlying aggradational geometries. Considering the seismic resolution as a limitation, interpreting this as an abrupt change in depositional trend could be misleading. However, the downlapping patterns clearly mark another event, genetically different from the underlying carbonate factory. A few possible explanations for this shift may be:
1. A lag time and re-establishment of the carbonate factory may have occurred between the sub-units S3a and $\mathrm{S} 3 \mathrm{~b}$. If this was the case, the underlying keep-up cycle must have terminated for a particular period before a new factory was established at another location. There is no clear seismic evidence of exposure between the sub-units S3a and S3b, but such a feature may lie below seismic resolution.

2. The development of local mounds was due to a significant increase in the carbonate growth potential under decreasing accommodation (see Fig. 8c). This would imply that the underlying keep-up cycle continues until the end of the seismic unit S3.

3. A transgressive event may have temporarily shut down the carbonate factory, due to a significant rise in sea level, but could not develop a seismic scale reflection. In this case, a drop in sea level at a later point of time re-established the carbonate factory, which was prograding toward the north and northwest.

In summary, the entire stage is characterized by largescale aggrading margins until the end of seismic unit 3 (SB3b). Further, this unit is onlapped by a thin transgressive event of the seismic unit S4 overlain by normal regressive events of the seismic unit 5. This entire stage is interpreted as a localized keep-up cycle, with the subsequent drowning of buildups M2 and M3 (Fig. 15c). The margins of buildup M4 became starved and accumulated vertically to form an escarpment surface with a relief of approximately $1100 \mathrm{~m}$ (velocity $4500 \mathrm{~m} / \mathrm{s}$ ), with progressively steepening slopes reaching angles between $15^{\circ}$ and $20^{\circ}$. The buildup M4 growth continued until the next fall in sea level (SB6), which apparently marks a depositional hiatus and subaerial exposure on seismic scale as high amplitude (Figs. 14, 15d). This observation matches with more erratic log values and infers a possible karst development. However, the impact of this exposure is not observed in the limited record provided by the well cuttings. An alternative interpretation for the discontinuous and mounded facies could also infer the presence of patch reefs in the shallow lagoon, enclosed by reef rims similar to examples provided by numerous ancient and modern carbonate buildups. The topographic lows between these buildups received some of the platform-derived sediments characterized by strong amplitudes with hummocky reflections (Figs. 9, 15).

\section{Late-stage buildup and final drowning stage (S7)}

Following the exposure event which interrupted the formation of S6, the platform was inundated again by a rise in relative sea level, thus re-establishing a neritic carbonate production. During this time, the increase in accommodation space restricted the carbonate factory to the eastern 
margin of the M4 buildup. In this scenario, the carbonate factory did not have an opportunity to re-occupy the full platform. It rather formed a distinctive mound, approximately $120 \mathrm{~m}$ thick and covering a surface of $8 \mathrm{~km}^{2}$. This growth episode is herein referred to as late-stage buildup (Fig. 15e). The surrounding platform area at this time was covered by hemipelagics and pelagics. The gradual change from shallow marine benthic foraminifera to deep marine planktonic species is recorded, which is indicative of the deepening paleoenvironment. From the biostratigraphic data, it appears that the shallow water carbonate factory completely drowned during the Early Eocene followed by the pelagic deposition, which persisted, from the Middle Eocene to the Middle Miocene (see Fig. 14). This hemipelagic to pelagic episode terminated with the advance of the southward prograding Miocene Indus Fan. The platform was, therefore, buried under a thick pile of Neogene to Recent siliciclastics turbidites and marine shales.

\section{Factors controlling the carbonate platform growth and architecture}

The Indus Basin is a classical area for the development of models for the facies, the stratigraphy and the paleoenvironmental evolution of Paleogene neritic carbonates (Akhter and Butt 1999; Afzal et al. 2011). In this study, for the first time, an overview of the geometrical and sequence stratigraphic evolution of these depositional systems is introduced, along with an insight into global and regional factors controlling the buildups growth in the region.

\section{Subsidence and eustatic sea level changes}

In the line of previous studies (Mohan 1985; Agrawal and Rogers 1992; Calvès et al. 2008), the subsidence history of western Indian margin can be separated into a main thermal subsidence phase, linked with the Early Paleocene volcanism and coeaval development of the passive margin, and a secondary phase of the flexuring induced subsidence by the loading of excessive Indus fan sediments and accompanied by the Indian Plate reorganization (Mohan 1985; Agrawal and Rogers 1992; Whiting et al. 1994). The first phase of thermal subsidence further consists of a slow subsidence during Late Paleocene to Early Eocene and a rapid subsidence event occurred thereafter.

The stratigraphic development of the carbonate platform in the Offshore Indus Basin was controlled by thermal subsidence. This continuous subsidence was responsible for creating the accommodation space for the growth of an approximately $1400 \mathrm{~m}$ thick shallow marine carbonate succession. During this time, the carbonate platform continuously reduced its surface area between the seismic units S1-S7, from 1650 to $260 \mathrm{~km}^{2}$, without any interruption by a margin progradational phase. However, the contemporaneous intraplatform progradation and the subaerial exposure of the platform suggest that the main global eustatic changes can still be recognized as a secondary overprint despite the strong control on deposition by subsidence. Further, a gradual change in the carbonate facies, from shallow marine limestone to the deep marine pelagic, is an indicative of a rapid change in accommodation space where the carbonate platform could not keep pace with the relative sea level rise and drowned. Calvès et al. (2008) connected this demise of platform with the rapid subsidence by thinning and cooling of the lithosphere. It was further speculated that the Indian margin shows significant slow thermal subsidence until Middle Eocene ( 37 Ma) which was followed by an episode of a rapid subsidence.

The present study, on a contradictory note, presents a different age of the platform drowning. Results derived from the biostratigraphic data propose an age bracket of $\sim 49$ to $45 \mathrm{Ma}$ for the onset of the drowning of the carbonate platform. This infers that the rapid subsidence started prior to this time, where initial slow subsidence is recorded within the time span of 16-20 Ma. This resulted in the deposition of thick limestone units. These results validate the drowning age suggested by Carmichael et al. (2009). However, the exposure surface preceding the development of the late-stage buildup is suspicious. We propose that a high-amplitude eustatic sea level lowering occurred in the corresponding time interval that may be responsible for the platform emersion. Although the herein presented biostratigraphic data are inadequate to document the precise age and interval of the emersion, the best correlation of the emersion preceding the late-stage buildup seems to match with an eustatic fall of more than $100 \mathrm{~m}$ around ca. 49 and 51 Ma (Miller et al. 2011; Haq et al. 1987) (Fig. 3b: global sea level).

\section{Climate and paleoceanography}

The type of carbonate producers and rate of deposition are known to be strongly influenced by climate (Jones and Desrochers 1992; Schlager 2005). The carbonate succession of the Greater Indus Basin was dominated by larger benthic foraminifera during the Paleogene period. This period witnessed long-term climatic changes that led to the transition from global greenhouse conditions to icehouse conditions (Zachos 2001). Scheibner and Speijer (2008a) suggested that Paleogene global warming events caused a Tethyan-wide massive decline in coral reefs and a coeval shift of carbonate platforms with large benthic foraminifera.

Scheibner and Speijer (2008b) subdivided the evolution of Paleogene Tethyan carbonate platforms into three stages linked to climate perturbations. Platform Stage I 
( 58.9 to 56.2 Ma; SBZ 1-3) is represented by the dominance of coralgal assemblages throughout the Tethys. Platform Stage 2 ( 56.2 to $\sim 55.5 \mathrm{Ma}$; SBZ 4-5) is linked with a noticeable reduction of coral taxa and a proliferation of larger foraminifera communities such as ranikothalids and micellanids in lower latitudes $\left(0^{\circ}-20^{\circ}\right)$ with a global rise in sea surface temperature, and Platform Stage III ( 55.5 to 40.4; SBZ 5/6-16) with a massive transient temperature peak causing a Tethyan-wide scarcity of coral communities. At the same time, Paleocene ranikothalids and miscellanids were substituted by nummulitids and alveolinids at the Paleocene-Eocene limit. This evolutionary trend is known as larger foraminifera turnover (LFT) and is directly coupled to the CIE of the PETM (Scheibner et al. 2005). The drilled section of carbonate platform sequences S5-S7 shows a high abundance of Nummulites and Alveolina species. This may assist in treating this part of carbonate succession to Platform Stage III of the Tethyan carbonate platforms. Undoubtedly, the lower platform part, which is more than $1000 \mathrm{~m}$ thick, records the LFT but this needs further drilling for confirmation. Correspondingly, the seismic units overlying SB3 show a decrease in relative thickness with the absence of any seismic mound facies. This is taken as an indication that a turnover of the type of carbonate factory occurred after this time and the lowest carbonate production rates due to the lack of a mound-building capacity can be expected.

The Early Paleogene climate perturbation climaxed with the EECO responding to a decline in the global temperatures. The global cooling event was accompanied by the demise of many symbiont-bearing larger benthic foraminifers species and a recovery of coral taxa in the southern Tethys (Hallock et al. 1991; Höntzsch et al. 2013). This persistent cooling trend eventually led to a glacial climate condition near the Eocene-Oligocene boundary (Kent and Muttoni 2008). The EECO is apparently not a signature in the platform, but its possible effects cannot be neglected in final demise of the carbonate platform.

Hallock (1987) presumed that the Paleogene evolutionary events of large benthic and planktonic foraminifera were linked to the effects of varying trophic resources in the oceans, resulting in eutrophic conditions on the continental shelves. Further, Speijer and Wagner (2002) outlined the intensification of deeper water upwelling on the continental shelf bordering the Tethyan Ocean. Considering these scenarios, the orientation of the Indian margin during the Late Paleocene was almost $-32^{\circ}$ clockwise from the present-day position (Copley et al. 2010). The Indopacific seaways were not closed yet and acted as a passage for ocean currents to the western Tethys (Scotese 2001). Perhaps these conditions developed a local geostrophic flow along the western margins of the Indian Plate, which enhanced the seasonal upwelling and productivity in the surface water with a possible additional influence of trade winds. Scotese and Summerhayes (1986) predicted the presence of upwelling phenomena during the Early Eocene, which might be a source of seasonally induced nutrient influx in the Offshore Indus Basin. As a consequence, the deposition of organic-rich shale occurred along the coast of the western Indian margin during the Late Paleocene to Early Eocene, which is taken as an evidence of an increase in productivity (Ahmad and Ahmad 2005). Such enhanced eutrophic conditions on the continental shelves may have been a factor for controlling the proliferation of the large benthic foraminifera.

\section{Partial drowning mechanism of the carbonate platform}

Tropical shallow water carbonate factories drown if the rate of increase of accommodation exceeds the carbonate growth and accumulation rate (Schlager 1981; Kim et al. 2012) and growth and accumulation rates are reduced through ecological disturbance and the platform submerged beneath the photic zone (Schlager 1981; Hallock and Schlager 1986).

Our results suggest that the flanks of carbonate platform show asymmetric growth. The eastern margin shows continuous aggrading margins whereas the western margins stepped back episodically during its growth to form three successive terraces. These types of terraces are also identified within the other modern and ancient carbonate systems. The reason of such terrace formation is attributed to the differential tectonics, changes in climate and biota, and environmental conditions (Ward 1999; Betzler et al. 2009; Fürstenau et al. 2010; Courgeon et al. 2016). The origin of this asymmetrical appearance of the platform margins, on the studied platform, is not entirely clear because of the data restraints. By comparison with the other platforms in the region, several hypotheses can be formulated to explain the external architecture of the platform history.

1. The western margin of the platform could be a response of differential subsidence subjected to the Cenozoic reorganization of the Indian Plate with respect to Arabian-African Plate. However, this hypothesis cannot be fully tested on this platform as the seismic data resolution also abruptly decreases beneath the carbonate platform due to the sub-basalt-imaging problem. Therefore, resolving the basement faults which could reflect such a process is not possible on 2D seismic.

2. Courgeon et al. (2016) also reported successive terrace formation in an Early Paleogene carbonate bank in the Mozambique Channel seamounts. This example was proposed to be associated with the major long-term climatic warming of the Paleocene-Eocene transition during which many Tethyan coral reef system declined. 
3. The backstepping could also be the response of environmentally triggered eutrophic regimes in the western Indian Ocean as seen in the archipelago of the Maldives (Betzler et al. 2009, 2016), the South China Sea (Zampetti et al. 2004). It is suggested that the deterioration of the environmental conditions are linked with the trade-wind driven upwelling as discussed earlier. Eventually, this nutrient injection threatened the carbonate factory and the platform could not keep-up with the relative sea level rise in aforementioned scenarios.

Nevertheless, future drilling, high-resolution geochemical, and microfacies analysis of the western margin of the platform may help to test the validity of these hypotheses.

\section{Seismic geomorphology and biota in comparisons with the Indo-Pacific carbonate platforms}

Subsurface examples of Paleocene and Eocene carbonate platforms were rarely documented in the past. Examples with a similar architecture and morphology as the case described herein are the Maldives (Purdy and Betram 1993; Aubert and Droxler 1996) and the Yadana platforms (Paumard et al. 2017). In all examples, the accommodation space for carbonate sedimentation is provided by the thermal subsidence of the volcanic pedestal. The carbonate platforms developed during a greenhouse time and internally contain an apparent layer cake stratigraphy with meter scale stratigraphic cycles. The stratigraphic geometries are largely aggradational in these platforms, escorted by the steep slopes descending to oceanic depths and apparently lacks wave resistant reefs structures. In terms of biota, the quoted examples also share similarities with an abundance of benthic foraminifera such as nummulites. The Paleogene succession in Maldives persisted until the Late Oligocene time (Aubert and Droxler 1996). The Indus offshore example, on the contrary, drowned at the end of Early Eocene. This confirms that, albeit the platforms are comparable in stratigraphy and morphology, the regional climatic and tectonic settings had a strong imprint on Indus Offshore carbonate platforms.

\section{Conclusions}

Detailed investigation of Paleocene-Eocene carbonates of Offshore Indus Basin yields a record of an isolated carbonate platform system, which developed on top of the Deccan volcanics with a minimum structural deformation. The 2D seismic stratigraphic architecture and the biostratigraphic data obtained from the well suggest that a longterm sea level rise, induced by the post-Deccan thermal subsidence, contributed significantly to the generation of the accommodation space required for the thick carbonate succession. Eustatic-induced short-term relative sea level changes acted as primary factors that influenced the internal heterogeneity and sequence formation, which could be resolved over the seismic scale as third-order cycles.

The presence of an Early Eocene benthic assemblage with nummulitid and Alveolinids allows assigning the platform to the Tethyan Platform Stage III. The climatic changes associated with PETM such as LFT caused a severe reduction in carbonate production. Hence, it is concluded that the global climate perturbation and rapid subsidence made the carbonate factory and the sediment accumulation vulnerable to high-frequency relative sea level fluctuations and, thus, eventually led to the platform drowning during the Early Eocene.

Acknowledgements The authors wish to express sincere thanks to the Directorate General of Petroleum Concession (DGPC), Pakistan and Hydrocarbon Development Institute of Pakistan (HDIP) for their permission to release and publish the analyzed dataset. We would like to acknowledge the assistance of Mr. Muhammad Zafar Iqbal and Mr. Faisal Mehmood (HDIP) in the preparation of well cutting samples and thin sections. We thank Schlumberger for providing the Petrel application and dGB Netherland for providing OpendTect software. Stephan J. Jorry and Wolfgang Schlager are thanked for providing constructive reviews that greatly improved this manuscript. The University of Hamburg is gratefully acknowledged for funding and scholarship.

\section{References}

Afzal J, Williams M, Aldridge RJ (2009) Revised stratigraphy of the lower Cenozoic succession of the Greater Indus Basin in Pakistan. J Micropalaeontol 28:7-23. doi:10.1144/jm.28.1.7

Afzal J, Williams M, Leng MJ et al (2011) Evolution of Paleocene to Early Eocene larger benthic foraminifer assemblages of the Indus Basin, Pakistan. Lethaia 44:299-320. doi:10.1111/j.1502-3931.2010.00247.x

Agrawal A, Rogers JJW (1992) Structure and tectonic evolution of the western continental margin of India: Evidence from subsidence studies for a 25-20 Ma plate reorganization in the Indian Ocean. In: Bartholomew MJ, Hyndman DW, Mogk DW, Mason R (eds) Basement tectonics 8: characterization and comparison of ancient and Mesozoic Continental Margins. Springer, Dordrecht, pp 583-590

Ahmad A, Ahmad N (2005) Paleocene petroleum system and its significance for exploration in the southwest lower Indus basin and nearby offshore of Pakistan. In: Proceedings of annual technical conference, 2005. Islamabad, pp 1-22

Akhter M, Butt AA (1999) Lower Tertiary biostratigraphy of the Kala Chitta Range, northern Pakistan. Revue de Paleobiologie 18:123-146

Aubert O, Droxler AW (1996) Seismic stratigraphy and depositional signatures of the Maldive carbonate system (Indian Ocean). Mar Pet Geol 13:503-536. doi:10.1016/0264-8172(96)00008-6

Berggren WA (2005) A revised tropical to sub-tropical Paleogene planktonic foraminiferal zonation. J Foraminifer Res 35:279298. doi:10.2113/35.4.279

Betzler C, Kroon D, Reijmer JJG (2000) Synchroneity of major Late Neogene sea level fluctuations and paleoceanographically 
controlled changes as recorded by two carbonate platforms. Paleoceanography 15:722-730. doi:10.1029/1999PA000481

Betzler C, Hübscher C, Lindhorst S et al (2009) Monsoon-induced partial carbonate platform drowning (Maldives, Indian Ocean). Geology 37:867-870

Betzler C, Fürstenau J, Lüdmann T et al (2013) Sea-level and ocean-current control on carbonate-platform growth, Maldives, Indian Ocean. Basin Res 25:172-196. doi:10.1111/j.1365-2117.2012.00554.x

Betzler C, Eberli GP, Kroon D et al (2016) The abrupt onset of the modern South Asian Monsoon winds. Sci Rep 6:29383. doi:10.1016/0031-0182(91)90075-3

Calvès G, Clift PD, Inam A (2008) Anomalous subsidence on the rifted volcanic margin of Pakistan: no influence from Deccan plume. Earth Planet Sci Lett 272:231-239. doi:10.1016/j. epsl.2008.04.042

Calvès G, Schwab AM, Huuse M et al (2011) Seismic volcanostratigraphy of the western Indian rifted margin: the preDeccan igneous province. J Geophys Res Solid Earth 116:128. doi:10.1029/2010JB000862

Carmichael SM, Akhter S, Bennett JK et al (2009) Geology and hydrocarbon potential of the offshore Indus Basin, Pakistan. Pet Geosci 15:107-116. doi:10.1144/1354-079309-826

Chatterjee S, Goswami A, Scotese CR (2013) The longest voyage: tectonic, magmatic, and paleoclimatic evolution of the Indian plate during its northward flight from Gondwana to Asia. Gondwana Res 23:238-267. doi:10.1016/j.gr.2012.07.001

Clift PD, Shimizu N, Layne GD et al (2001) Development of the Indus Fan and its significance for the erosional history of the Western Himalaya and Karakoram. Geol Soc Am Bull 113:1039-1051. doi:10.1130/0016-7606(2001)113<1039:DOT IFA $>2.0 . \mathrm{CO} ; 2$

Copley A, Avouac J-P, Royer J-Y (2010) India-Asia collision and the Cenozoic slowdown of the Indian plate: implications for the forces driving plate motions. J Geophys Res Solid Earth 115:B03410. doi:10.1029/2009JB006634

Courgeon S, Jorry SJ, Camoin GF et al (2016) Growth and demise of Cenozoic isolated carbonate platforms: new insights from the Mozambique Channel seamounts (SW Indian Ocean). Mar Geol 380:90-105. doi:10.1016/j.margeo.2016.07.006

de Groot P, Huck A, de Bruin G et al (2010) The horizon cube: a step change in seismic interpretation. Lead Edge 29:10481055. doi:10.1190/1.3485765

Duncan RA (1990) The volcanic record of the Reunion hotspot. In: Backman J, Peterson L, Duncan RA (eds) Proceedings of the Ocean Drilling Program, Scientific Results, vol 115, pp 3-10

Edwards RA, Minshull TA, White RS (2000) Extension across the Indian-Arabian plate boundary: the Murray Ridge. Geophys J Int 142:461-477. doi:10.1046/j.1365-246x.2000.00163.x

Embry AF (1993) Transgressive-regressive (T-R) sequence analysis of the Jurassic succession of the Sverdrup Basin, Canadian Arctic Archipelago. Can J Earth Sci 30:301-320. doi:10.1139/ e93-024

Fontaine JM, Cussey R, Lacaze J et al (1987) Seismic interpretation of carbonate depositional environments. AAPG Bull 71:281-297

Fürstenau J, Lindhorst S, Betzler C, Hübscher C (2010) Submerged reef terraces of the Maldives (Indian Ocean). Geo-Mar Lett 30:511-515. doi:10.1007/s00367-009-0174-2

Gaedicke C, Schlüter H-U, Roeser HA et al (2002) Origin of the northern Indus Fan and Murray Ridge, Northern Arabian Sea: interpretation from seismic and magnetic imaging. Tectonophysics 355:127-143. doi:10.1016/S0040-1951(02)00137-3

Hallock P (1987) Fluctuations in the trophic resource continuum: a factor in global diversity cycles? Paleoceanography 2:457-471. doi:10.1029/PA002i005p00457
Hallock P, Glenn EC (1986) Larger foraminifera: a tool for paleoenvironmental analysis of Cenozoic carbonate depositional facies. Palaios 1:55. doi:10.2307/3514459

Hallock P, Schlager W (1986) Nutrient excess and the demise of coral reefs and carbonate platforms. Palaios 1:389. doi: $10.2307 / 3514476$

Hallock P, Premoli Silva I, Boersma A (1991) Similarities between planktonic and larger foraminiferal evolutionary trends through Paleogene paleoceanographic changes. Palaeogeogr Palaeoclimatol Palaeoecol 83:49-64. doi:10.1016/0031-0182(91)90075-3

Haq B (1981) Paleogene paleoceanography: Early Cenozoic oceans revisited. Oceanol Acta Special Issue 4:71-82

Haq BU, Hardenbol J, Vail PR (1987) Chronology of fluctuating sea levels since the Triassic. Science 235:1156-1167. doi:10.1126/ science.235.4793.1156

Höntzsch S, Scheibner C, Kuss J et al (2011) Tectonically driven carbonate ramp evolution at the southern Tethyan shelf: the Lower Eocene succession of the Galala Mountains, Egypt. Facies 57:51-72. doi:10.1007/s10347-010-0229-x

Höntzsch S, Scheibner C, Brock JP, Kuss J (2013) Circum-Tethyan carbonate platform evolution during the Palaeogene: the Prebetic platform as a test for climatically controlled facies shifts. Turk J Earth Sci 22:891-918. doi:10.3906/yer-1207-8

Hottinger L (1971) Larger foraminifera common to Mediterranean and Indian Paleocene and Eocene formations. Ann Hung Geol Inst 54:143-150

Jerram DA, Single RT, Hobbs RW, Nelson CE (2009) Understanding the offshore flood basalt sequence using onshore volcanic facies analogues: an example from the Faroe-Shetland basin. Geol Mag 146:353. doi:10.1017/S0016756809005974

Jones B, Desrochers A (1992) Shallow platform carbonates. In: Walker R, James N (eds) Facies models-response to sealevel changes. Geological Association of Canada, St. John's, pp 277-301

Jorry S, Davaud E, Caline B (2003) Controls on the distribution of Nummulite facies: a case study from the Late Ypresian El Garia Formation (Kesra Plateau, Central Tunisia). J Pet Geol 26:283306. doi:10.1111/j.1747-5457.2003.tb00031.x

Jorry SJ, Hasler C-A, Davaud E (2006) Hydrodynamic behaviour of Nummulites: implications for depositional models. Facies 52:221-235. doi:10.1007/s10347-005-0035-z

Kent DV, Muttoni G (2008) Equatorial convergence of India and Early Cenozoic climate trends. Proc Natl Acad Sci USA 105:16065-16070

Kim W, Fouke BW, Petter AL et al (2012) Sea-level rise, depthdependent carbonate sedimentation and the paradox of drowned platforms: slowly drowned platforms. Sedimentology 59:16771694. doi:10.1111/j.1365-3091.2012.01321.x

Lucia FJ (2007) Carbonate reservoir characterization. Springer, Berlin

Malod JA, Droz L, Kemal BM, Patriat P (1997) Early spreading and continental to oceanic basement transition beneath the Indus deep-sea fan: northeastern Arabian Sea. Mar Geol 141:221-235. doi:10.1016/S0025-3227(97)00074-1

Miller K, Mountain G, Wright J, Browning J (2011) A 180-millionyear record of sea level and ice volume variations from continental margin and deep-sea isotopic records. Oceanography 24:4053. doi:10.5670/oceanog.2011.26

Mitchum RM, Vail PR, Sangree JB (1977) Seismic stratigraphy and global changes of sea level: Part 6. Stratigraphic interpretation of seismic reflection patterns in depositional sequences. In: Payton CE (eds) Seismic stratigraphy - applications to hydrocarbon exploration, vol 26. American Association of Petroleum Geologists, Tulsa, pp 117-134

Mohan M (1985) Geohistory analysis of Bombay High region. Mar Pet Geol 2:350-360. doi:10.1016/0264-8172(85)90030-3 
Mresah MH (1993) Facies patterns and stratal geometries: clues to the nature of the platform margin during the Paleocene, northeast Sirte Basin, Libya. Sediment Geol 84:149-167. doi:10.1016/0037-0738(93)90052-7

Naini BR, Talwani M (1982) Structural framework and the evolutionary history of the continental margin of Western India: rifted margins: field investigations of margin structure and stratigraphy. In: Warkins JS, Drake CL (eds) Studies in continental margin geology, vol 34. American Association of Petroleum Geologists, Tulsa, pp 167-191

Paumard V, Zuckmeyer E, Boichard R et al (2017) Evolution of Late Oligocene-Early Miocene attached and isolated carbonate platforms in a volcanic ridge context (Maldives type), Yadana field, offshore Myanmar. Mar Pet Geol 81:361-387. doi:10.1016/j. marpetgeo.2016.12.012

Purdy EG, Betram GT (1993) Carbonate concepts from the Maldives, Indian Ocean. American Association of Petroleum Geologists, Studies in Geology 34:1-57

Qayyum F, de Paul G, Hemstra N (2012) Using 3D Wheeler diagrams in seismic interpretation-the HorizonCube method. First Break 30:103-109

Qayyum F, Hemstra N, Singh R (2013) A modern approach to build 3D sequence stratigraphic framework. Oil Gas J 111:46-65

Robinson SA (2011) Shallow-water carbonate record of the Paleocene-Eocene Thermal Maximum from a Pacific Ocean guyot. Geology 39:51-54. doi:10.1130/G31422.1

Ryan WBF, Carbotte SM, Coplan JO et al (2009) Global multiresolution topography synthesis. Geochem Geophys Geosyst 10:Q03014. doi:10.1029/2008GC002332

Sandwell DT, Muller RD, Smith WHF et al (2014) New global marine gravity model from CryoSat-2 and Jason-1 reveals buried tectonic structure. Science 346:65-67. doi:10.1126/ science. 1258213

Sarg JF (1988) Carbonate sequence stratigraphy. In: Wilgus CK, Hastings BS, Posamentier H, van Wagnor J, Ross CA, Kendall CGSC (eds) Sea-level changes: an integrated approach. SEPM (Society of Sedimentary Geology) Special Publication No. 42, Tulsa, pp 155-182

Sarg JF, Markello J, Weber LJ (1999) The second-order cycle, carbonate-platform growth, and reservoir, source, and trap prediction. In: Harris PM, Saller AH, Simo JA (eds) Advances in carbonate sequence stratigraphy. SEPM (Society for Sedimentary Geology), Tulsa, pp 11-34

Scheibner C, Speijer RP (2008a) Decline of coral reefs during Late Paleocene to Early Eocene global warming. eEarth 3:19-26. doi:10.5194/ee-3-19-2008

Scheibner C, Speijer RP (2008b) Late Paleocene-Early Eocene Tethyan carbonate platform evolution - a response to long- and short-term paleoclimatic change. Earth Sci Rev 90:71-102. doi:10.1016/j.earscirev.2008.07.002

Scheibner C, Speijer RP (2009) Recalibration of the Tethyan shallow-benthic zonation across the Paleocene-Eocene boundary: the Egyptian record. Geol Acta 7:195-214. doi: $10.1344 / 105.000000267$

Scheibner C, Speijer RP, Marzouk AM (2005) Turnover of larger foraminifera during the Paleocene-Eocene Thermal Maximum and paleoclimatic control on the evolution of platform ecosystems. Geology 33:493. doi:10.1130/G21237.1

Scheibner C, Rasser MW, Mutti M (2007) The Campo section (Pyrenees, Spain) revisited: implications for changing benthic carbonate assemblages across the Paleocene-Eocene boundary. Palaeogeogr Palaeoclimatol Palaeoecol 248:145-168. doi:10.1016/j. palaeo.2006.12.007

Schlager W (1981) The paradox of drowned reefs and carbonate platforms. Geol Soc Am Bull 92:197. doi:10.1130/0016-7606(1981)92<197:TPODRA >2.0.CO;2
Schlager W (2005) Carbonate sedimentology and sequence stratigraphy. SEPM (Society for Sedimentary Geology), Tulsa

Schlager W, Camber O (1986) Submarine slope angles, drowning unconformities, and self-erosion of limestone escarpments. Geology 14:762. doi:10.1130/0091-7613(1986)14<762:SSADU $\mathrm{A}>2.0 . \mathrm{CO} ; 2$

Scotese CR (2001) Atlas of Earth history, vol 1. Paleogeography. PALEOMAP Project, Arlington, Texas

Scotese CR, Summerhayes CP (1986) Computer model of palaeoclimate predicts coastal upwelling in the Mesozoic and Cenozoic. Geobyte 1:28-42

Serra-Kiel J, Hottinger L, Caus E et al (1998) Larger foraminiferal biostratigraphy of the Tethyan Paleocene and Eocene. Bulletin de la Société Géologique de France 169:281-299

Speijer RP, Wagner T (2002) Sea-level changes and black shales associated with the late Paleocene thermal maximum: organicgeochemical and micropaleontologic evidence from the southern Tethyan margin (Egypt-Israel). In: Koeberl C, MacLeod KG (eds) Catastrophic events and mass extinctions: impacts and beyond. Geological Society of America Special Paper 356, pp 533-549

Talwani M, Reif C (1998) Laxmi Ridge-a continental sliver in the Arabian Sea. Mar Geophys Res 20:259-271. doi:10.102 3/A:1004674909280

Todal A, Edholm O (1998) Continental margin off Western India and Deccan large igneous province. Mar Geophys Res 20:273-291. doi:10.1023/A:1004640508371

Torsvik TH, Amundsen H, Hartz EH et al (2013) A Precambrian microcontinent in the Indian Ocean. Nat Geosci 6:223-227. doi:10.1038/ngeo1736

Wade BS, Pearson PN, Berggren WA, Pälike H (2011) Review and revision of Cenozoic tropical planktonic foraminiferal biostratigraphy and calibration to the geomagnetic polarity and astronomical time scale. Earth Sci Rev 104:111-142. doi:10.1016/j. earscirev.2010.09.003

Wandrey C, Law B, Shah HA (2004) Sembar-Goru/Ghazij composite total petroleum system, Indus and Sulaiman-Kirthar Geologic Provinces, Pakistan and India. U.S. Geological Survey Bulletin 2208-C 1:1-23

Ward WB (1999) Tectonic control on backstepping sequences revealed by mapping of Frasnian backstepped platforms, Devonian reef complexes, Napier Range, Canning Basin, Western Australia. In: Harris PM, Saller AH, Simo JA (eds) Advances in carbonate sequence stratigraphy. SEPM (Society for Sedimentary Geology) Special Publication No. 63, Tulsa, pp 47-74

White R, McKenzie D (1989) Magmatism at rift zones: the generation of volcanic continental margins and flood basalts. J Geophys Res Solid Earth 94:7685-7729. doi:10.1029/JB094iB06p07685

Whiting BM, Karner GD, Driscoll NW (1994) Flexural and stratigraphic development of the west Indian continental margin. J Geophys Res Solid Earth 99:13791-13811. doi:10.1029/94JB00502

Zachos J (2001) Trends, rhythms, and aberrations in global climate $65 \mathrm{Ma}$ to present. Science 292:686-693. doi:10.1126/ science. 1059412

Zamagni J, Mutti M, Košir A (2008) Evolution of shallow benthic communities during the Late Paleocene-earliest Eocene transition in the Northern Tethys (SW Slovenia). Facies 54:25-43. doi:10.1007/s10347-007-0123-3

Zampetti V, Schlager W, van Konijnenburg J-H, Everts A-J (2004) Architecture and growth history of a Miocene carbonate platform from 3D seismic reflection data; Luconia province, offshore Sarawak, Malaysia. Mar Pet Geol 21:517-534. doi:10.1016/j. marpetgeo.2004.01.006 